NBER WORKING PAPER SERIES

\title{
TRACING THE IMPACT OF BANK LIQUIDITY SHOCKS: EVIDENCE FROM AN EMERGING MARKET
}

\author{
Atif Mian \\ Asim Ijaz Khwaja \\ Working Paper 12612 \\ http://www.nber.org/papers/w12612
NATIONAL BUREAU OF ECONOMIC RESEARCH
1050 Massachusetts Avenue
Cambridge, MA 02138
October 2006

We are extremely grateful to the State Bank of Pakistan (SBP) for providing the data used in this paper. Our heartfelt thanks to Abid Qamar at SBP for clarifying many data related questions, and Oscar Vela for his research assistance. The results in this paper do not necessarily represent the views of the SBP. We also thank Jeffrey Frankel, Robert Lawrence, Anil Kashyap, David Scharfstein, Daniel Paravisini and numerous seminar participants for helpful comments and suggestions. All errors are our own. The views expressed herein are those of the author(s) and do not necessarily reflect the views of the National Bureau of Economic Research.

(C) 2006 by Atif Mian and Asim Ijaz Khwaja. All rights reserved. Short sections of text, not to exceed two paragraphs, may be quoted without explicit permission provided that full credit, including $\odot$ notice, is given to the source. 
Tracing the Impact of Bank Liquidity Shocks: Evidence from an Emerging Market

Atif Mian and Asim Ijaz Khwaja

NBER Working Paper No. 12612

October 2006

JEL No. E44,E5,E51,G21,G3

\begin{abstract}
$\underline{\text { ABSTRACT }}$
Do liquidity shocks matter? While even a simple 'yes' or `no' presents identification challenges, going beyond this entails tracing how such shocks to lenders are passed on to borrowers, and whether borrowers can in turn cushion these shocks through the credit market. This paper does so by using data that follows all loans made by lenders to borrowing firms in Pakistan, and exploiting cross-bank variation in liquidity shocks induced by the unanticipated nuclear tests in 1998. We isolate the causal impact of the bank lending channel by showing that for the same firm borrowing from two different banks, its loan from the bank experiencing a $1 \%$ larger decline in liquidity drops by an additional $0.6 \%$. The liquidity shock also lowers the probability of continued lending to old clients and extending credit to new ones. Although this lending channel affects all firms significantly, large firms and those with strong business and political ties completely compensate the effect by borrowing more from more liquid banks - both through existing and new banking relationships. In contrast, small unconnected firms are entirely unable to hedge and face large drops in overall borrowing and increased financial distress. The liquidity shocks thus have large distributional consequences.
\end{abstract}

Atif Mian

University of Chicago

Graduate School of Business

5807 South Woodlawn Avenue

Chicago, IL 60637

and NBER

atif@chicagogsb.edu

Asim Ijaz Khwaja

JFK School of Government

Harvard University

79 JFK Street

Cambridge, MA 02138

asim_ijaz_khwaja@harvard.edu 
Banks around the world, particularly in emerging markets, often face large shocks to their supply of liquidity. ${ }^{1}$ These shocks may be driven by changes in monetary policy, speculative bank runs, "hot money" flows, or exchange rate volatility. Many observers argue that banks pass on these fluctuations to borrowing firms even when there is no change in the firms' overall credit worthiness. Such financial shocks can have large real effects if firms that receive banking shocks are unable to smooth them. ${ }^{2}$

Investigating banks as a conduit for transmitting financial shocks thus requires estimating both the bank lending channel - the inability of banks to cushion borrowing firms against shocks to the banks' liquidity supply, and the firm borrowing channel - the inability of firms to smooth out bank-lending channel effects by borrowing from alternative sources of financing.

Existing work provides increasing evidence on the first channel (Kashyap et. al., 1993; Peek and Rosengren, 1997; Kashyap and Stein 2000; Paravisini, 2006). Related studies also consider the impact of liquidity shocks on economic outcomes and find significant real effects of the supply shocks arguing they may be to blame for economic recessions (Bernanke 1983; Peek and Rosengren, 2000). Yet others find liquidity shock impacts to be insignificant (Ashcraft, 2006) or varying by firm type (Gertler and Gilchrist, 1994; Kashyap, Lamont and Stein 1994). This suggests that the firm borrowing channel may be the critical factor in determining whether and how the bank lending channel gets transmitted to the economy. However, investigating this has proven difficult.

The difficulty in simultaneously estimating the bank lending and firm borrowing channels stems from identification concerns as well as the unavailability of micro-level data linking banks to firms. Identification concerns arise because events that trigger changes in liquidity supply, such as monetary policy innovations or deposit shocks are often accompanied by changes in investment returns and consequently, credit demand. Changes in firm borrowing therefore reflect both changes in credit supply as well as credit demand. This paper proposes a new empirical methodology for identifying the bank lending channel and uses a loan-level panel data set to estimate bank lending and firm borrowing channels simultaneously.

A simple example illustrates our methodology for identifying the bank lending channel, and

\footnotetext{
${ }^{1}$ For example, the average standard deviation of the real cost of deposits is $1.6 \%$ in G7 countries but $12.9 \%$ in 25 major emerging markets, and the standard deviation of real demand deposit growth is $14 \%$ and $24 \%$ respectively (IMF International Financial Statistics, 1980-2005).

${ }^{2}$ For example, work such as Fisher (1933), Bernanke (1983), Calomiris and Mason (2003) attribute the great depression to such banking crises.
} 
estimating the firm borrowing channel. Consider two banks in an economy, one of which (bank A) experiences a negative liquidity supply shock while the other (bank B) experiences no change. Bank A might restrict its lending after the negative shock, but that cannot be fully attributed to the bank lending channel since firms borrowing from bank A might simultaneously have received a negative liquidity demand shock. Such positive correlation between supply shocks to banks and demand shocks to firms is the main identification problem in the literature.

Our solution to this problem comes from focusing on firms that borrowed from both banks $\mathrm{A}$ and $\mathrm{B}$ at the time of the shock, and then comparing how loans to the same firm from bank A change relative to loans from bank B. This within firm difference-in-differences strategy translates into putting firm fixed effects after first-differencing the loan level data. Since firm fixed effects absorb the entire firm specific change in credit demand, the estimated difference in loan changes within the same firm can be plausibly attributed to differences in bank level liquidity shocks, i.e. the bank lending channel. ${ }^{3}$

Identifying the bank lending channel is not sufficient though since its ultimate impact on firms also depends on the firm borrowing channel. In our example above, if the affected firms can borrow more from other banks, such as bank B or a third bank $\mathrm{C}$, then the lending channel will have no real impact on the economy. Tracing such borrowing channels requires that one observe a firm's borrowing from each bank separately over time. We could then test whether firms that initially borrowed from bank A were able to compensate from other banks or not.

The methodology described above requires unanticipated liquidity shocks to the banking sector that vary across banks, and loan level data that links firms to each lender before and after shocks. We implement this methodology using a natural experiment induced by the unexpected nuclear tests in Pakistan in 1998 along with a quarterly loan-level panel data (1996-2000) that represents the universe of corporate lending in the country (18,000 firms).

When Pakistan announced testing of its nuclear weapons a fortnight after similar tests by India in 1998, the government - in anticipation of the balance of payment problems - forced banks with dollar-denominated deposit accounts to withhold payments in dollars. These banks could only pay back their dollar deposit holders in local currency at an unfavorable exchange rate. Such partial defaults triggered large withdrawals of deposits from banks with dollar deposits. Since banks differed significantly in what fraction of their deposits were in dollar-denominated

\footnotetext{
${ }^{3}$ Section IV.D. discusses some remaining identification concerns in detail.
} 
accounts, nuclear tests generated significant cross-bank variation in shocks to their deposit base.

Using the loan-level data set, we first focus on firms borrowing from multiple banks at the time of the nuclear tests and use the firm fixed effects methodology to identify the bank lending channel. Our within firm comparison reveals that a percentage point larger decline in bank liquidity supply leads to $0.6 \%$ reduction in loan amount by the bank. There is also a large lending channel effect on the extensive margin: a $1 \%$ fall in bank liquidity reduces the probability of lending to new clients by 12 basis points and the probability of continuing lending to existing clients by 21 basis points. The bank lending channel works through its impact on quantity as we find no evidence of change in price of loans due to bank liquidity shocks.

The firm fixed effects approach provides an unbiased estimate of the lending channel since the shocks are unanticipated and one need not rely on the potentially contentious assumption that bank level credit supply shocks are uncorrelated with firm level credit demand shocks. The downside of this approach is that it restricts analysis to firms with multiple banking relationships. However, by comparing our unbiased fixed effect estimate with its biased OLS counterpart, we can prove empirically that nuclear tests induced a negative correlation between credit supply and credit demand shocks. The negative correlation makes the OLS estimate a conservative measure of the bank lending channel effect. We can thus expand our analysis to the full sample, and doing so shows that lending channel is present for all types of firms.

The estimated negative cross-sectional correlation between liquidity supply and demand shocks is plausible because, as we show later, banks that received larger negative shocks to their liquidity supply (i.e. banks with more dollar deposits) were better banks lending to better firms. If these firms were better able to cope with the changing macro environment, then their credit demand shocks will be less adverse relative to firms at other (unaffected) banks.

We next estimate firm borrowing channel. Large firms (i.e. top 30\% of firms by size) are able to undo the entire bank lending channel shock by borrowing more from more liquid banks. Similarly, "connectedness" helps firms to compensate the bank lending channel shocks. Firm connectedness is proxied by whether the firm is part of large business networks or whether it has a politician in its board of directors. Smaller unconnected firms on the other hand are unable to hedge the bank lending channel and face large overall borrowing drops. Splitting the firm borrowing channel between existing and new relationship banks, we find that large borrowers equally compensate their lending channel loan loss by borrowing from (relatively) more liquid 
banks with whom they had pre-existing relationships and from new relationship banks.

The inability of small and unconnected firms to undo the negative effects of lending channel shocks affects their financial outcomes as well. For example, within small firms, a firm that borrows from a bank with a one percent larger decline in liquidity, is $2 \%$ more likely to enter into financial distress a year after the nuclear tests. On the other hand there is no such effect within large firms, consistent with the finding that large firms can hedge lending channel shocks.

While theoretical work, such as Bernanke and Blinder (1988), Bernanke and Gertler (1989), Holmstrom and Tirole (1997), and Stein (1998), emphasizes that transmission of financial shocks to the real economy requires credit market imperfections at both the bank and firm level, empirical literature has mostly focused on the banking side. Our paper differs in simultaneously testing for market frictions at the bank and firm level.

Literature on the bank lending channel started with papers such as Bernanke and Blinder (1992), Bernanke (1983), and Bernanke and James (1991), that used time-series correlations between changes in liquidity and changes in loans (or output) to argue that liquidity shocks have real consequences. The concern that these time series correlations may be confounded by economy wide productivity shocks then led to work such as Gertler and Gilchrist (1994), Kashyap, Lamont, and Stein (1994), Kashyap and Stein (2000) and Ashcraft (2006) that use cross-sectional variation in liquidity supply across banks or firms to purge out economy levels shocks. Others use instrumental variables (Paravisini; 2006) or look for natural experiments (Peek and Rosengren, 1997, 2000; Ashcraft, 2005) that generate exogenous (to demand) liquidity supply shocks. In contrast, our methodology need not make any identifying assumptions about liquidity supply and demand shocks correlation. Instead, by using firm fixed effects, we purge out all firm-specific credit demand changes in order to isolate the bank lending channel.

The firm fixed effects strategy also allows us to sign the liquidity supply and demand shocks correlation and show that OLS provides conservative estimates. Since loan-level data sets of the type used in our paper are becoming increasingly available, our strategy is generalizable to other environments for identification and understanding the bias in OLS estimates.

Our results highlight the usefulness of simultaneously estimating firm borrowing channel. While we find that the bank lending channel is large and present for all types of firms, an important subset of firms are able to undo the financial impact of bank lending channel. The inability of small and unconnected firms to substitute away the bank lending channel shocks 
means that financial shocks can have significant distributional consequences.

In what follows, section I describes the data and the institutional background. Section II presents our empirical methodology. Sections III, IV and V provide results concerning the bank lending and firm borrowing channels, and whether these channels have any impact on firm financial distress. Section VI concludes.

\section{Institutional Background and Data}

\section{A. The 1998 Liquidity Crunch}

Unanticipated nuclear tests by India on 11th May 1998 led to retaliatory nuclear tests by Pakistan on the 28th of May. These events led to a large and sudden liquidity shock for banks in Pakistan. The extent of this shock varied across banks depending on their exposure to dollar denominated deposit accounts. We outline the sequence of events that led to these changes.

\section{Dollar Deposit Accounts}

By the early 1990s Pakistan had a relatively liberalized banking sector with significant private and foreign bank participation. Banking reforms during this period included the introduction of foreign currency (mostly dollar) deposit accounts in Pakistan. The scheme was aimed at stopping the flight of dollars oversees by allowing citizens to hold foreign currency within Pakistan.

An important feature of the dollar accounts was that local banks accepting dollar deposits could not retain dollars. Banks had to surrender dollars to the central bank, the State Bank of Pakistan (SBP), in return for rupees at the prevalent exchange rate. When a depositor demanded his dollars (with interest) back, the bank obtained dollars from the central bank in exchange for rupees at the initial (i.e. time of deposit) exchange rate. Therefore all exchange rate risk between the time of deposit and the time of withdrawal was borne by the central bank (see SBP notification \#54, June 7, 1992) and the SBP charged banks a $3 \%$ annual fee for providing this insurance. Given currency devaluation trends, these dollar deposit accounts were widely popular and by May 1998, in a span of six years, dollar deposits had grown to $43.5 \%$ of total deposits in Pakistan.

However, the exposure to dollar deposits was not uniform across banks. As of December 1997 the percentage of a bank's deposits denominated in dollars varied from $0 \%$ to $98 \%$, with a 
standard deviation of $27 \%$. This cross-bank variation was clearly not exogenous and depended on a host of factors such as the customer base of a bank, its marketing strategy, and its perceived outlook. In particular, as we show in section (II), better and more profitable banks held a higher percentage of dollar deposits.

\section{"Freeze" on Dollar Deposit Accounts}

When India and Pakistan tested nuclear devices in May 1998, the international community moved swiftly to impose sanctions on both countries. The sanctions were limited to military sales and financial assistance, and did not involve any major trade sanctions. However, suspension of exchange rate liquidity support from the IMF led to balance of payment problems for Pakistan.

Anticipating these problems, the Prime Minister of Pakistan, along with the announcement of the nuclear tests on May 28th, declared that all foreign currency accounts would be "partially frozen". This meant that dollar deposit holders could only withdraw money in rupees at the current and disadvantaged exchange rate. The freeze thus amounted to a partial default on dollar deposits by the government, with depositors losing 10-15\% of their deposit value.

The loss of confidence as a result of this partial default turned out to have a serious impact on the banking sector. Dollar deposit holders withdrew their money from banks despite only being able to do so at disadvantaged exchange rates. Figure I traces the aggregate dollar deposits over time and shows the sudden and precipitous withdrawal from dollar accounts after the nuclear tests with these deposits falling by a half within a year of the freeze.

Part of this liquidity exited the Pakistani banking system, as it was converted back into dollars through the black market and invested abroad. Since the deposit run was experienced by banks with larger dollar deposit accounts, the liquidity shock varied substantially across banks, with several rupee deposit reliant banks continuing to enjoy pre-nuclear test deposit growth.

The nuclear tests thus lead to sharp cross-sectional variation in deposit-led liquidity shocks experienced by banks. Figure II illustrates this variation for all the forty two commercial banks that issued demandable deposits in local and foreign currency. It plots the average annual change in liquidity for these banks from December 1997 to December 1999 against their prenuclear test reliance on dollar deposits. Each observation is plotted proportional to bank size in December 1997. The graph shows a strong negative relationship between dollar deposit 
exposure and changes in bank liquidity. ${ }^{4}$ We exploit this feature in our estimation strategy in section II.

While the nuclear induced liquidity shocks are somewhat unique in their origin and lack of anticipation, the magnitude of these shocks is fairly representative of liquidity shocks experienced by Pakistan and other emerging markets historically. While the 1998 events reduced the growth in deposits from $17 \%$ to $5 \%$, the Pakistani economy experienced such low deposit growth on at least 4 separate occasions in the prior two decades. The high volatility of the banking sector in Pakistan is also very representative of other emerging markets. The standard deviation of real annual growth rates of demand deposits was 15.8\% (1.65 times the mean growth rate) in Pakistan during 1980-2005 compared to 24\% (2.1 times the mean growth rate) for 26 major emerging markets. ${ }^{5}$ In fact such variability is also present in developed economies, with G7 countries experiencing a standard deviation of demand deposit growth of $13.7 \%$ during the same time period.

The banking sector in Pakistan is also liberal and representative of emerging markets. Private, foreign and government banks constitute roughly equal shares of domestic lending. Financial reforms in the early 90s brought uniform prudential regulations in-line with international banking practices (Basel accord) and autonomy was granted to the State Bank of Pakistan (SBP) for regulation. While political efforts have been made in the past to bring banking in accordance with Islamic shariah laws, it has not had any significant functional impact on banking. For all practical purposes banking follows global norms with deposit and lending rates determined by the market.

\section{B. Data}

Our primary data comes from the credit information bureau (CIB) of SBP. The central bank maintains this data to monitor and regulate the lending activities of banks. It has quarterly loan-level information on the universe of corporate bank loans outstanding in Pakistan between July 1996 and March 2000. The data includes the history of each loan with information on the amount and type of loan outstanding, default amounts and duration. It also has information on the name, location and board of directors of the borrowing firm and its bank. We combine

\footnotetext{
${ }^{4}$ Changes in deposits refer to book values and hence are not too much influenced by current price fluctuations.

${ }^{5}$ The numbers are based on International Financial Statistics (IFS) data and 26 major emerging markets included in the Morgan Stanley global equity index (MSCI).
} 
this data with annual balance sheet information on banks.

In terms of data quality, our personal examination of the collection and compilation procedures, as well as consistency checks on the data suggest that it is of high quality. CIB was part of a large effort by the central bank to setup a reliable information sharing resource that all banks could access. Perhaps the most credible signal of data quality is the fact that all local and foreign banks refer to information in CIB on a daily basis to verify the credit history of prospective borrowers. We checked with one of the private banks in Pakistan and found that they use CIB information about prospective borrowers explicitly in their internal credit scoring models. We also ran several internal consistency tests on the data such as aggregation checks, and found the data to be of excellent quality. As a random check, we also confirmed the authenticity of the data from a bank branch by comparing it to the portfolio of that branch's loan officer.

Although the original data includes 145 financial intermediaries, for most of our analysis we will restrict our sample to the 42 commercial banks that were allowed to open demandable deposits (including dollar deposits). The remaining financial intermediaries had private or institutional sources of funding and are excluded because we do not have information on their changes in liquidity. The sample restriction however should not be a big concern for two reasons. First, the excluded financial intermediaries only make up $22 \%$ of overall lending at the time of nuclear tests. Second, since the excluded institutions were not taking dollar or rupee deposits, they were unlikely to have been significantly affected by the nuclear tests. Therefore including them in our sample makes no qualitative difference to the results of this paper. However, we do include lending by all these financial intermediaries when we examine aggregate firm outcomes such as overall firm borrowing and default rates, since these intermediaries could play an important role in hedging firms against the bank-lending channel shocks.

We use the above data to analyze the impact of the liquidity crunch resulting from the nuclear tests of May 1998. Our starting point is the set of all performing private business loans given out by the 42 commercial banks at the time of nuclear tests. This gives us a sample of 22,176 loans to 18,647 firms. A "loan" in our paper is defined as a bank-firm pair. There are more loans than firms since a single firm may borrow from multiple banks. Although we have quarterly data on the 22,176 loans from July 1996 to March 2000, for most of the analysis we collapse our quarterly time dimension into equal duration single "pre" and "post" nuclear test 
periods by taking time-series averages of loans. ${ }^{6}$ This time-collapsing of data has the advantage that our standard errors are robust to concerns of auto-correlation (see Bertrand, Duflo and Mullainathan, 2004).

Table I presents summary statistics for the loan, firm and bank level variables in our primary data set. Since our data covers the universe of all business loans, there is large variation in loan sizes. For example, the average loan size is about 16 million rupees, median is 2.5 million rupees, and the 99th percentile loan is 230 million rupees. Given the large size variation, we checked both size-weighted and un-weighted results to ensure that our conclusions are neither entirely driven by the large number of very small loans, nor a small number of very large loans. The table also presents loan distribution across firms by different firm attributes such as size, political connections, membership in business conglomerates and others. A firm is considered politically connected if one of its directors is a politician. It is considered to be a "conglomerate" firm if it is a member of a large network of firms that are linked through common directors i.e. inter-locked boards. These attributes are explained in detail in the appendix.

In some of the empirical specifications run, we expand the sample in Table I to include new firms financed by commercial banks after nuclear tests (18,299 loans), as well as loans given out by the 103 non-commercial banks.

\section{Empirical Methodology}

This section outlines a simple econometric model that highlights the traditional identification problem in the lending channel literature and how our firm fixed effects approach addresses it. We then describe how we use our approach to go beyond the bank lending channel and estimate the extent to which firms are able to compensate their lending channel shocks.

\section{A. Estimating the Bank Lending Channel: The traditional identification problem}

Consider a two period model with bank $i$ providing financing to firm $j$ each period. For simplicity, assume that a bank can only lend to one firm while firms can borrow from multiple

\footnotetext{
${ }^{6}$ The time-series averages are taken after converting all values to real 1995 rupees. Moreover, we exclude the quarter of the nuclear tests from these calculations. The pre-shock period covers July 1996 through March 1998 while post-shock period covers July 1998 through March 2000.
} 
banks. $^{7}$ In the first period $t$, a bank and firm negotiate a loan of size $L_{i j}^{t}$. The bank finances this loan by issuing demandable deposits $D_{i}^{t}$, and seeking alternative financing $B_{i}^{t}$ (such as equity, bonds etc.). Since $L_{i j}^{t}$ is the only bank asset, the following accounting identity must hold:

$$
D_{i}^{t}+B_{i}^{t} \equiv L_{i j}^{t}
$$

Models of the lending channel such as Stein (1998) are based on costly external financing. We incorporate this feature by assuming that banks can raise deposits costlessly but only up to $\bar{D}_{i}^{t}$. Beyond this limit, it is costly to raise additional financing $\left(B_{i}^{t}\right)$ with the marginal cost given by $\left(\alpha_{B} * B_{i}^{t}\right)$ where $\alpha_{B}>0$. The overall bank credit supply function $\left(D_{i}^{t}+B_{i}^{t}\right)$ is thus linear in the cost of funds.

On the credit demand side, we assume that the marginal return loan $L_{i j}^{t}$ is decreasing in size and given by $\left(\bar{r}_{j}-\alpha_{L} L_{i j}^{t}\right)$. The equilibrium amounts of $B_{i}^{t}$ and $L_{i j}^{t}$ are thus determined by the intersection of linear supply and demand curves in each period.

At the end of first period $t$, the economy (i.e. banks and firms) receives two types of shocks. The first, a "credit supply" shock, determines the level of deposits available to each bank in period $t+1$. In particular, the supply of deposits for bank $i$ in $t+1$ is given by $\bar{D}_{i}^{t+1}=\bar{D}_{i}^{t}+\bar{\delta}+\delta_{i}$, where $\bar{\delta}$ and $\delta_{i}$ are economy wide and bank-specific shocks respectively. The second shock is a "credit demand" shock that firm $j$ experiences in the form of a shock to its productivity. In particular, the marginal return on its loan $L_{i j}^{t+1}$ next period is now given by: $\bar{r}_{j}-\alpha_{L} L_{i j}^{t+1}+\bar{\eta}+\eta_{j}$. The productivity shock $\left(\bar{\eta}+\eta_{j}\right)$ reflects an economy wide and a firm-specific component respectively.

Given the linear set up of our model, equilibrium each period is determined by jointly solving the FOC ${ }^{8}$ and accounting identity (1) for $L_{i j}$ and $B_{i}$. Solutions for the two periods (assuming away corner solutions) can then be combined into a single first-differenced equation:

$$
\Delta L_{i j}=\frac{\alpha_{B}}{\left(\alpha_{L}+\alpha_{B}\right)}\left(\bar{\delta}+\delta_{i}\right)+\frac{1}{\left(\alpha_{L}+\alpha_{B}\right)}\left(\bar{\eta}+\eta_{j}\right)
$$

Equation (2), although derived from an admittedly simple model, highlights some important issues. First, it shows the importance of costly external financing. Without this assumption

\footnotetext{
${ }^{7}$ We want to emphasize here that our purpose is not to build a fully specified model of bank intermediation. We shall deliberately only focus on those features that highlight the fundamental econometric issues.

${ }^{8}$ The FOC is $\alpha_{B} B_{i}^{t}=\bar{r}-\alpha_{L} L_{i j}^{t}$ in period $t$, and $\alpha_{B} B_{i}^{t+1}=\bar{r}+\bar{\eta}+\eta_{j}-\alpha_{L} L_{i j}^{t+1}$ in period $t+1$.
} 
(i.e. with $\alpha_{B}=0$ ), banks would be in a Modigliani-Miller world and shocks to deposits or "liquidity shock" $(\delta)$ would have no impact on equilibrium loan amounts. Second, and more importantly, equation (2) highlights the identification problem in estimating the causal impact of a liquidity shock on loans. This can be seen more easily by re-writing (2) as:

$$
\Delta L_{i j}=\frac{1}{\left(\alpha_{L}+\alpha_{B}\right)}\left(\alpha_{B} * \bar{\delta}+\bar{\eta}\right)+\frac{\alpha_{B}}{\left(\alpha_{L}+\alpha_{B}\right)} \delta_{i}+\frac{1}{\left(\alpha_{L}+\alpha_{B}\right)} \eta_{j}
$$

The first term on the RHS of (3) is just a constant reflecting economy wide shocks. Thus first-differencing takes out all secular time trends in the economy through the constant term. Let $\beta_{0}\left(=\frac{1}{\left(\alpha_{L}+\alpha_{B}\right)}\left[\alpha_{B} * \bar{\delta}+\bar{\eta}\right]\right)$ denote this constant. The second term on the RHS contains the main coefficient of interest. Let $\beta_{1}=\frac{\alpha_{B}}{\left(\alpha_{L}+\alpha_{B}\right)}$, then $\beta_{1}$ captures the "lending channel" for each incremental unit of deposits lost. The OLS regression typically run to estimate (3) is:

$$
\Delta L_{i j}=\beta_{0}+\beta_{1} * \Delta D_{i}+\eta_{j}+\varepsilon_{i j}
$$

where $\Delta D_{i}=\delta_{i}$ represents the bank-specific change in deposits. However, the estimate . $O L S$

$\beta_{1} \quad$ in (4) will be biased if $\operatorname{Corr}\left(\Delta D_{i}, \eta_{j}\right) \neq 0$. This isolates the fundamental problem: In general $\Delta D_{i}$ and $\eta_{j}$ are likely to be positively correlated. For example, liquidity shocks $\left(\Delta D_{i}\right)$ such as bank runs are more likely to occur in banks that receive some bad news $\left(\eta_{j}\right)$ about the quality or productivity of the firms they lend to.

\section{B. An Unbiased Estimate of the Lending Channel: Firm Fixed Effects}

A positive correlation between $\Delta D_{i}$ and $\eta_{j}$ leads to an over-estimate of $\beta_{1}$ if (4) is estimated using OLS because $\hat{\beta}_{1}=\beta_{1}+\frac{\operatorname{Cov}\left(\Delta D_{i}, \eta_{j}\right)}{\operatorname{Var}\left(\delta_{i}\right)}$. We adopt a new method for identifying the lending channel $\beta_{1}$ by introducing firm fixed effects $\beta_{j}$ in (4):

$$
\Delta L_{i j}=\beta_{j}+\beta_{1} * \Delta D_{i}+\varepsilon_{i j}
$$

Since the fixed effects $\beta_{j}$ are introduced after first-differencing the data, they absorb all firmspecific credit demand shocks $\eta_{j}$. The FE approach thus tests whether the same firm borrowing from two different banks experiences a larger decline in lending from the bank that faces a relatively greater fall in it's liquidity supply. Since the comparison is done across banks for the 
same firm, all firm specific demand shocks are absorbed by the firm fixed effect. ${ }^{9}$ However, we can only estimate the fixed effects coefficient $\beta_{1}$ in the sample of firms that have multiplebanking relationships.

While the fixed effects strategy does not require or make any assumptions about the correlation between liquidity supply and demand shocks (since the latter is absorbed by the firm fixed effect) one would prefer that the liquidity supply shock be unanticipated. This is the case in the natural experiment examined in this paper. The concern is that if such shocks are anticipated, banks may adjust their lending or firms adjust their borrowing prior to the shock. This would lead to either an under or overestimate of the bank lending channel depending on the direction of the pre-shock loan adjustments. Unanticipated shocks remove such concerns since no pre-shock adjustments are made.

Although firm fixed effects address the main identification concerns expressed in the literature, there may remain some additional questions. For example, perhaps a firm's loan demand is bank specific and is correlated with shocks to the bank's liquidity. For example, this can happen if, (i) nuclear shocks disproportionately effect export demand, (ii) firms get "export related" loans from banks that specialize in exports, and (iii) these export intensive banks had more dollar deposits and thus suffered a larger liquidity crunch as well. We shall address this and other related concerns in detail in section IV D.

\section{Estimating the Firm Borrowing Channel}

We also utilize the firm fixed effects estimates of the bank lending channel to provide conservative estimates of the firm borrowing channel. The latter channel examines whether firms can negate the effects of adverse lending channel shocks from existing banks by borrowing from more liquid banks. Furthermore, if they are unable to do so, can they draw on internal/informal resources or will they instead enter financial distress?

Let $Y_{j}^{t}$ be a firm level attribute of interest in period $t$ (such as a firm's total borrowing from all banks or it's average default rate on these loans). Then the reduced form firm borrowing

\footnotetext{
${ }^{9}$ This argument is slightly more subtle. Once we recognize a bank lends to multiple firms, equation (3) has to be modified to include idiosyncratic demand shocks experienced by these other " $-j$ " firms. The firm fixed effect will only absorb firm $j$ 's demand shock and the other " $-j$ " firms' demand shocks that comove with $j$ 's demand shock. However, since these remaining components are, by construction, orthogonal to $j$ 's demand shock, $\beta_{1}$, is identified. Put another way, all one requires for identification is that firm $j$ 's bank experiences a net (of other firms' demands) liquidity supply shock that is orthogonal to firm $j$ 's credit demand.
} 
channel can be determined by estimating the following first-differenced equation:

$$
\Delta Y_{j}=\beta_{0}^{F}+\beta_{1}^{F} * \Delta \bar{D}_{j}+\eta_{j}
$$

where $\Delta \bar{D}_{j}$ is the average liquidity shock faced by firm $j$ 's pre-shock banks. If the firm borrowing channel completely insulates a firm from loan specific bank lending channels, then liquidity shocks to a firm's banks should have no net impact on the firm's borrowing, i.e. $\beta_{1}^{F}$ should be zero.

Equation (6) has the same identification concerns as equation (4), namely that $\Delta \bar{D}_{j}$ might be positively correlated with $\eta_{j}$. However, unlike before, we can no longer put in firm fixed effects since (6) is aggregated to the firm level. We therefore adopt a different strategy based on the nature of nuclear test induced liquidity shocks to estimate $\beta_{1}^{F}$. Suppose we could prove that the circumstances generating the liquidity shocks $\left(\Delta \bar{D}_{j}\right)$ actually led to a negative correlation between $\Delta \bar{D}_{j}$ and unobserved demand shocks $\left(\eta_{j}\right)$. Then even an OLS estimate of $\beta_{1}^{F}$ in equation (6) is useful as it gives us an underestimate of the true effect.

\section{How are bank liquidity and loan demand shocks correlated in the cross-section?}

Liquidity supply and demand shocks are likely to be positively correlated in the time-series in general for reasons mentioned earlier. However, it is less clear whether these shocks are positively correlated cross-sectionally i.e. across lenders at a given point in time. In our case we in fact demonstrate that the nuclear tests induced liquidity demand and supply shocks are negatively correlated in the cross-section. We first show evidence in favor of this claim and then provide an empirical test to check whether the correlation is indeed negative in data.

Figure II shows that banks with greater proportion of dollar deposits experienced larger declines in liquidity. Columns (1) and (2) of Table II confirm the statistical significance of this relationship both in terms of t-stats as well as R-sq. Column (2), which weighs each observation by bank size and is thus economically more meaningful, shows that a $1 \%$ increase in the percentage of dollar deposits held by a bank prior to nuclear tests leads to a $0.30 \%$ decline in bank liquidity. The R-sq is also high at $40 \%$. Columns (3) through (6) show that although the dollar reliant banks suffered larger liquidity declines, they were initially lending to better quality firms. This is reflected by the fact that more dollar reliant banks had significantly lower default rates, and significantly higher profitability. Similar results are obtained if we replace percentage dollar deposits with actual deposit change on the RHS i.e. banks that experienced 
larger declines in deposits were initially more profitable and had lower defaults. ${ }^{10}$

If more profitable firms are better able to adapt to adverse macro shocks induced by the nuclear tests, then our assertion that $\Delta \bar{D}_{j}$ and $\eta_{j}$ are negatively correlated is valid. While the evidence in Table II is suggestive, we can also offer a more direct test for the negative correlation by using the FE estimate from equation (5). Since $\hat{\beta}_{1}$ provides an unbiased estimate of $\beta_{1}$, we can write $\hat{\beta}_{1}=\hat{\beta}_{1} \hat{F E}+\frac{\operatorname{Cov}\left(\Delta D_{i}, \eta_{j}\right)}{\operatorname{Var}\left(\delta_{i}\right)}$. Thus the difference between the OLS estimate $\beta_{1}$ and the FE estimate $\beta_{1}$ provides a direct test of how $\Delta D_{i}$ is correlated with $\eta_{j}$. In the results section we will show that the OLS estimate is smaller than the FE estimate in the same sample of multiple-bank firms for which we run the FE estimate. Thus $\operatorname{Corr}\left(\Delta \bar{D}_{i}, \eta_{j}\right)<0$ and the OLS estimates of firm-level outcomes will be under-estimates. ${ }^{11}$

We should note that the assumption we are implicitly making here is that the same selection that applies to multiple-bank firms (for which we can estimate the bank lending channel by using firm fixed effects) also holds for single-bank firms. In other words, banks with better multiple-relationship firms also have better single-relationship firms. This is not only plausible, but examining the equivalent of Columns (3)-(6) in Table II restricting to loans only to singlerelationship firms shows the same pattern - banks with greater liquidity shocks do have better single-relationship firms.

\section{Results: Non-parametric patterns}

We first describe our main findings through simple non-parametric graphs. The subsequent regressions will show that the same patterns hold under more demanding specifications. Our non-parametric analysis is based on the 18,647 firms that were borrowing at the time of the nuclear tests and were not in default.

\footnotetext{
${ }^{10}$ One could argue here that although banks with more dollar deposits were of better quality, they might systematically lend to those firms whose liquidity demand "co-moves" with the bank's supply of liquidity (see Kashyap, Rajan and Stein (2002) for the full theoretical argument). If this were true then more dollar reliant banks would also experience larger liquidity demand shocks. While the argument is valid in general, it is unlikely to apply in our context because of the exchange rate insurance provided by the central bank. The insurance implied that banks did not have an incentive to try to hedge exchange rate fluctuation when making lending decisions.

${ }^{11}$ While our argument is in terms of the bank-specific liquidity shock, $\delta_{i}$, and a firm's demand shock, $\eta_{j}$, equation (6) aggregates the bank-specific liquidity shocks across all of firm $j$ 's banks. However, it is easy to show that $\operatorname{Corr}\left(\delta_{i}, \eta_{j}\right)<0 \vee i \Longrightarrow \operatorname{Corr}\left(\Delta \bar{D}_{i}, \eta_{j}\right)<0$ since $\Delta \bar{D}_{i}$ is just a weighted average of the $\delta_{i}{ }^{\prime}$ s.
} 
Figure IIIa illustrates the bank-lending channel by separating loans to these firms into loans from "positive" and "negative" liquidity banks. Positive liquidity banks refer to banks that had above median growth in deposits after the (nuclear) shock, while negative liquidity banks refer to those with below median deposit growth. We aggregate loans within each bank category by quarter, and plot the logarithm of aggregate lending over time. Doing so puts greater weight on larger loans and ensures our results are economically meaningful. Log aggregate lending is normalized to zero in the quarter of nuclear tests (1998Q2). The y-axis values can thus be interpreted as growth rates in lending relative to the nuclear shock quarter.

The aggregate trends in figure IIIa provide revealing information regarding the bank lending channel and support for our identification strategy. First, the trend in lending before the shock is similar between positive and negative liquidity shock banks. Consequently any divergence in trend after the shock cannot be attributed to pre-existing differential trends. Second, there is a sharp divergence in trends right after the nuclear tests. This divergence in lending due to a bank's liquidity shock is the "bank lending channel" and it can be estimated as a doubledifference, i.e. the difference in lending between positively and negatively affected banks after the shock less the difference between the two before the shock.

The bank lending channel in figure IIIa is not driven by large firms alone. We classify firms as "large" if their average annual borrowing is in the top $30 \%$, and "small" otherwise. ${ }^{12}$ Figures III b-c repeat the analysis in Figure IIIa separately for large and small firms and show that the same patterns as before hold.

Figures IVa-b next examine the firm borrowing channel by asking what happens to a firm's overall borrowing after the shock. Specifically, we repeat the analysis of figure III but this time aggregate all loans across lenders for a given firm at each point in time. A firm is then grouped into the positive liquidity shock category if its bank(s) at the time of nuclear tests received above median liquidity shock on average (and the opposite for negative liquidity shock category). The figures show that large firms are completely able to compensate the adverse effects of the bank lending channel by borrowing more from new and existing liquid banks, but small firms are entirely unable to do so.

Figures $\mathrm{Va}$ and $\mathrm{Vb}$ then examine whether the firm borrowing channel (for smaller firms)

\footnotetext{
${ }^{12}$ Section V.D. diaggregates size categories by deciles, and justifies why we define the top three deciles as "large" and the rest as "small".
} 
also affects a firm's overall financial strength. Figures Va-b repeat the analysis of figures IVa-b, but replace the y-axis by the average default rate of firms for the two categories of (positive and negatively liquidity shock) firms. The default rate is zero by construction before the nuclear tests since we exclude firms that were already in default at the time of the tests. Consistent with the results in figures IVa-b, we find that for large borrowers there is no impact of bank liquidity shocks at the firm level. If anything, firms borrowing from negative liquidity banks have a lower default rate. This supports our earlier claim that such (affected) banks had better quality firms. On the other hand within smaller firms, those borrowing from negative liquidity banks are significantly more likely to default, suggesting the lending channel identified earlier has real consequences for small (but not large) firms. The effect on default shows up a few quarters after the shock suggesting that firms are able to use internal/informal sources of credit to survive in the short run but cannot keep this up for long.

Figures III-V illustrate our main results and show that they are persistent. The next sections will show that these broad patterns hold up to more demanding empirical specifications and a variety of robustness tests.

\section{Results: The Bank Lending Channel}

Taking our empirical methodology to the data, we start with the time-collapsed loan level data described in section I, with a single pre and one post nuclear test observation for each loan. Alternatively, we could have estimated equation (5) in the time-series data by including firmquarter fixed effects. Doing so provides similar results but, as mentioned earlier, we prefer to collapse the time-dimension to obtain more conservative standard errors. For expositional convenience, we divide our analysis of the bank lending channel into two parts, an "intensive margin" referring to a reduction in the amount of lending to firms borrowing at the time of the liquidity shock, and an "extensive margin" referring to the denial of credit to existing borrowers and to new borrowers. 


\section{A. The Intensive Margin}

There were 22,176 performing loans to 18,647 firms at the time of the nuclear tests that continued borrowing some amount after the tests as well. ${ }^{13}$ Table III estimates the first-differenced specification (4). We regress the change in log loan amount as a result of the nuclear tests on the change in log bank liquidity. Since the liquidity shock occurs at the bank level, changes in loans from the same bank may be correlated. Therefore all our loan level regressions cluster errors at the bank level. Since there are only 42 banks in our main sample, standard errors are likely to be conservative.

Column (1) in Table III presents the preferred FE estimation strategy in equation (5) that provides an unbiased estimate of the bank lending channel coefficient. The FE sample is restricted to the 1,864 multi-bank firms with a total of 5,382 loans. The results indicate a large bank lending channel: A $1 \%$ decline in bank liquidity leads to $0.6 \%$ decline in the bank's loan to a firm. Since the firm fixed effects in column (1) are added after first differencing the data, they absorb all time-varying firm-specific factors including firm credit demand shocks. Columns (2) and (3) show that this result is robust to adding bank and loan-level controls, including loan-type interacted with firm fixed effects. We will return to these results in more detail when we discuss robustness issues at the end of the section.

Figure VI graphically illustrates how the firm FE approach addresses the concern of supplydemand correlation by holding fixed the identity of a firm across positive and negative liquidity banks. This figure is the graphical counterpart to the regression in column (1) and the firm fixed effects counterpart to figure IIIa. We start with the set of 1,864 firms (5,382 loans) that borrowed from multiple banks at the time of the nuclear tests. For each firm, we classify its bank as a "positive liquidity shock bank" if its liquidity shock is higher than the median liquidity shock for all banks lending to that firm. The remaining banks lending to that firm are classified as "negative liquidity shock banks". We then "de-mean" the (logarithm) loan amount by subtracting the (logarithm of) average loan size at the firm level in each quarter. The figure then plots the firm's demeaned loan amounts for it's positive and negative liquidity banks. Figure VI shows that on average there is no significant difference between loans taken

\footnotetext{
${ }^{13}$ For the intensive margin sample we exclude firms that immediately and entirely stop borrowing from their bank(s) after the shock i.e. firms that don't borrow anything in every post-shock period. Such firms show up as large outlyers in our first-difference log-specification and would therefore unduly influence our estimates. Including these firms only increases the magnitude of our estimates.
} 
by the same firm from positive and negative liquidity banks before the nuclear tests. However once the liquidity shock hits, there is a sudden and sharp divergence in loans given out by the two sets of banks to the same firm. Since firm level changes in loan demand are taken out by construction, figure VI provides a tight identification of the bank lending channel effect.

Column (4) estimates the OLS bank lending channel coefficient using the same multi-bank sample of column (1). The OLS coefficient drops to 0.46, compared to 0.60 for FE. As section II highlighted, the drop in the OLS coefficient implies that a bank's liquidity supply it's client firms' loan demand shocks are cross-sectionally negatively correlated. Consequently, OLS provides an underestimate of the true effect.

Column (5) repeats the OLS specification of column (4) on the full sample of firms. The bank lending channel coefficient is larger in the full sample, suggesting that the lending channel effect is larger for single relationship firms. We find in columns (6) and (7) that the lending channel is indeed stronger for smaller firms, where "small" refers to firms in the bottom $70 \%$ of the size distribution.

\section{B. The Extensive Margin}

Do bank liquidity shocks also impact the extensive margin of banks by forcing them to either stop lending to firms altogether or reducing the intake of new firms? We begin by testing if the "exit rate" of firms is higher in banks harder hit by the liquidity crunch. For each loan, we create a variable, EXIT, which is 1 if the loan is not renewed at some point during the first post-nuclear test year. As before, we use the firm FE approach to control for changes in loan demand at the firm level, and test whether the same firm borrowing from different banks is more likely to exit a negative liquidity shock bank. This translates into estimating the following FE specification on multi-bank firms:

$$
E X I T_{i j}=\beta_{j}+\beta_{1} * \Delta D_{i}+\varepsilon_{i j}
$$

$\beta_{1}$ is the coefficient of interest.

Column (1) in Table IV runs the FE specification and shows that a $1 \%$ reduction in bank liquidity leads to a 21 basis points increase in the probability of exit for a loan (that is about a $1 \%$ increase in probability since the mean exit rate for loans was $20.7 \%$ during this period). 
Column (2) shows that the result remains robust to adding pre-shock bank level controls such as the bank's return on assets, size, capitalization ratio, portfolio quality and ownership type.

Column (3) then examines whether smaller borrowers experience the same (or larger) impact. Since small borrowers typically borrow from a single bank only (and would therefore be absorbed by the firm fixed effect), we prefer to run an OLS specification on the full sample of firms. The results in Column (3) show there is no significant difference in exit rates in response to the liquidity shock between large and small borrowers. ${ }^{14}$

We next test if liquidity shocks also impact the ability of banks to make new loans. To do so, we start with all loans given out in the post nuclear test year (35,921 loans) and create a variable $E N T R Y$, which is 1 if the loan was first made in the post nuclear tests period. Using ENTRY as the LHS variable, we repeat the analysis presented in columns (1) through (3).

Column (4) shows that liquidity supply significantly impacts a bank's ability to issue new loans. A $1 \%$ reduction in bank liquidity reduces its probability of making a loan to a new client by 12 basis points (the mean entry rate in the data was 38.5\%). The firm fixed effects once again ensure that the entry effect is not driven by unobserved firm-level time-varying factors (such as shocks to credit demand). Column (5) shows that the effect remains robust to bank level controls. Columns (6) runs OLS in the full sample of firms, and shows that while large borrowers are more likely to start new relationships with positive liquidity banks, this effect is twice as large for small borrowers i.e. not only are small borrowers more likely to enter, they do so more (less) for banks with greater (lower) liquidity.

Tables III and IV show that bank liquidity shocks have large lending channel effects both on the intensive and extensive margins. The magnitude of these effects is also large. Since the standard deviation of bank liquidity shocks is $30 \%$ (Table I), a one standard deviation shock to bank liquidity leads to an $18 \%$ decline in lending, a 6.3 percentage points increase in the likelihood of exit, and a 3.6 percentage points decrease in the likelihood of new loan origination. The results suggest that the MM theorem breaks down at bank level, and shocks to the banking sector are transmitted to firms through changes in the banks' lending patterns.

\footnotetext{
${ }^{14}$ Using a non-linear probit model gives the same results as our linear specification. We prefer to use the linear model since the results are then comparable with the Firm FEs specification where we cannot use a probit model.
} 


\section{Do Liquidity shocks impact the price of loans?}

So far we have focused on the amount of loan given out by a bank. We now test whether in addition to this quantity effect, bank liquidity shocks also affect the price of loans i.e. the interest rate charged. While the loan level CIB data set does not record interest rates charged, another data source from the central bank records the average interest rate for loans of different sizes charged by a given bank branch at a point in time. This data can be used to proxy for the interest rate charged on a given loan using loan size and location information.

Using this data we compute the change in interest rates from December 1997 to December 1999 for each loan and regress this variable on change in log of bank liquidity as before. ${ }^{15}$ Column (1) in table $\mathrm{V}$ presents our preferred firm fixed effects specification and shows no statistically significant effect, i.e. a firm does not experience interest rate increases from its bank that experienced a greater liquidity fall relative to one that did not. Comparing within the same firm assures us that the interest rate comparison is not affected by any firm-level differences in credit demand etc.

Column (2) pushes this further by introducing loan-type interacted with firm fixed effects i.e. not only comparing interest rates across the same firm borrowing from two banks, but across the same firm borrowing the same type of loan across two different banks. Column (3) presents the OLS (and potentially biased) results in the full sample of firms. While the coefficient magnitude rises, so do standard errors. Column (4) examines whether the effect varies by firm size and finds no significant results. So while the bank lending channel affects the quantity of loan supply, it does not affect the average price charged by banks.

Note that the magnitude of the coefficient on change in liquidity is weakly positive, suggesting that even if there is a price effect, it is the opposite of what one would expect: Instead of negatively shocked banks raising their interest rates, they are more likely to drop them. This is not surprising if the liquidity drop causes banks to cut lending to marginally riskier borrowers that are typically charged higher interest rates. More generally, the small magnitude could also be because interest rates are constrained due to inter-bank loan competition, or because of a fear of increasing moral hazard concerns. We should caution that it could also simply be that our average interest rate information is not disaggregated enough to capture differences in interest rates at the loan-level across firms. This is unlikely though, since a general examination

\footnotetext{
${ }^{15}$ Out of the 42 commercial banks used in our analysis, interest rate information is available for 39 .
} 
of lending suggests there is not much variation in interest rates even at the loan level.

Our interest rate results are similar in spirit to Peterson and Rajan (1994) who find that closer ties between the firm and its creditor increases the availability of credit but does not lower the price of credit. This suggests that quantity rather than price is the more relevant margin in bank-firm relationships.

\section{Robustness to alternative explanations}

Although the firm fixed approach we use to identify the bank-lending channel resolves a number of empirical concerns by accounting for firm specific time-varying variables such as changes in a firm's credit demand and in other firm level attributes, we address some remaining concerns here.

\section{Loan-specific credit demand}

Firm fixed effects take out spurious credit demand concerns by absorbing changes in credit demand at the firm level. However, this may not be sufficient if a firm's credit demand is loan specific and shocks to loan demand are correlated with the bank liquidity shocks. For example, suppose that dollar reliant banks specialize in making longer term loans, and nuclear tests led to a disproportionate reduction in the demand for long term loans. Then, even in the absence of any bank lending channel, firms borrowing from dollar reliant banks will contract their relative borrowing from these banks.

We can test for such concerns using information on the type of loan taken by a firm. A loan in our data set can be classified as: (i) short term (under 6 months) working capital loans, (ii) longer term fixed loans, and (iii) non-funded loans such as guarantees and letters of credit. We then control for loan types non-parametrically by interacting firm fixed effects with loan type to ensure comparison of the same loan type and for the same firm across banks (this gives us 2,731 fixed effects for the 1,864 firms in the sample of firms with multiple pre-shock banks). The result in column (3) of Table III shows no significant change in the lending channel coefficient. It is also worth noting here that since most of the firms belong to traditional sectors such as textile and consumer goods, it is unlikely that firms take "specialized" loans in the first place.

A similar concern may be related to firms taking on export related loans from dollar reliant banks. If the export part of a firm's business suffered disproportionately more, then once again we will have a spurious within firm correlation between credit demand and bank liquidity 
shocks. We test for this concern (regression not shown) by limiting our fixed effect analysis to the 1,588 firms that do not export at all and find that the bank lending coefficient is unchanged (0.55 vs. 0.60 in column (1) of Table III).

\section{Heterogeneity in bank response to macro shocks}

Could the lending channel coefficient be driven by inherent differences in how banks respond to the shocks induced by the nuclear tests? This is possible if there is such response heterogeneity and it is systematically correlated with a bank's liquidity shock. For example, perhaps the lending channel estimate is picking up differences in how foreign and local banks react to nuclear tests since we know that foreign banks are more likely to deal in dollar deposits.

For example, suppose more dollar reliant banks (which we know are better banks ex-ante) are generally more "cautious" in making loans and therefore react more than other banks to a given firm productivity shock. Then dollar reliant banks, that also experience larger declines in deposits, might cut back lending to the same firm more, not because of a lack of liquidity, but because they want to reduce their loan portfolio risk more than less affected banks.

We test for such concerns by including various bank characteristics that proxy for such differential lending sensitivity as controls. Column (2) in Table III includes several pre nucleartest bank level controls such as the bank's return on assets, lagged deposit growth, bank size, capitalization ratio, fraction of portfolio in default, and dummies for foreign and government banks. ${ }^{16}$ Bank ROA, portfolio in default and capitalization ratios in particular are likely to capture a banks' sensitivity to client quality. The results indicate that the lending channel coefficient remains robust to all these bank level controls.

While unlikely, one may still worry that these pre-shock measures are not appropriate because they are not good proxies for the bank's quality sensitivity or even if they are initially, they are not after the shock. We can address this remaining concern more directly by examining changes in the quality of the bank's portfolio after the shock. If the differential quality sensitivity criticism is valid then the banks facing liquidity shocks should be relatively more unwilling to lend to firms experiencing negative productivity shocks and therefore their portfolio quality should (relatively) increase after the shock. In Table VIII we will directly examine changes in firm default rate and in fact show that the opposite is true - banks with greater liquidity shocks

\footnotetext{
${ }^{16}$ Pre-98 ROA, bank size, and capitalization rate are averages over fiscal years 1996 and 1997 (fiscal years end in december). Pre-98 deposit growth is calculated as growth in deposits from dec 1996 to dec 1997.
} 
see their client firms' default rates increase. Thus it cannot be that these banks are becoming more quality conscious than other banks.

\section{Other robustness and interpretational concerns}

A potential concern may be that the bank lending channel captures an initial differential cost of capital difference i.e. if banks had lower costs of capital on account of holding foreign currency accounts, then one may worry that their lending drop after the liquidity shock is not a result of the supply shock but a price correction (i.e. the removal of the cheaper source of capital). If this were the case then one would expect to see such banks raise the interest rates on their loans as a result of this price correction. However, the results in Table $\mathrm{V}$ show the opposite. Such negatively affected banks actually drop their interest rates although this result is not economically or statistically significant.

One should also point out an alternate "deposits as collateral" based explanation. To the extent that a firm's cash balances are informative about it's cash flows and offer liquid collateral, bank's may reduce lending to a firm simply because the firm draws down its cash reserves held as bank deposits. However, such level effects are taken into account by the firm fixed effects in our primary first-differenced specification. The firm-fixed effects strategy is called to question only if a bank gives greater weight to a firm's cash reserves that are held at the bank itself as compared to cash reserves held at others bank. This is particularly implausible for large firms, since banks have access to audited information regarding such firm's cash reserves and flows. Since the bank lending channel holds for such large firms as well, it seems unlikely that it is primarily driven by such collateral based explanations.

Finally, a concern might be that our FE results represent a "strategic" withdrawal by firms from hard hit banks. For example, a firm may choose to cut back borrowing from a bank facing liquidity problems and switch to more liquid banks for fear that the liquidity constrained bank might become insolvent in the future. However, this is unlikely since banks hit by the liquidity crunch were historically more profitable (as borne out in Table II) and, while they did see profitability decline post-shock, they still remained as profitable as the banks which did not loose liquidity. In fact, no bank declared insolvency after the nuclear tests.

It is worth noting that the last concern is more of an interpretational issue. Provided the loan decline is induced on account of the initial supply-side shock, i.e. firms borrow less from banks that were hit by a larger liquidity shock (that is exogenous to the firms' demand), one 
could interpret it as a bank lending channel.

\section{Results: Firm Level Impact}

\section{A. Can Firms Hedge Bank Specific Liquidity Shocks?}

We have seen that negative shocks to a bank's liquidity supply translate into a (causal) drop in its client firms' loans. However, such bank lending channels may not have any aggregate effect if firms can compensate for bank-specific loan losses by borrowing more from banks with greater liquidity. Unlike earlier empirical studies, we can test for the extent of such substitution since our data matches firms to all 145 bank and non-bank financial intermediaries in the economy.

So far we restricted our attention to the 42 commercial banks that used demandable deposits as their source of liquidity. Since a firm might use any commercial or non-commercial bank to compensate for the lending channel, we now include all the 145 financial intermediaries in our analysis and construct the aggregate loan amount borrowed by each firm from all of these intermediaries before and after the nuclear tests.

We then compute the average liquidity shock faced by each firm by constructing a loan-size weighted average of the change in deposits for the banks that the firm borrowed from before the nuclear tests. In constructing this aggregate liquidity shock at firm level, we assume that noncommercial banks experience the economy wide change in liquidity. Since the non-commercial banks only comprise $22 \%$ of the market share, this assumption is not crucial for our results. For example, assuming instead that non-commercial banks experience no change in liquidity does not change our results.

As discussed in section (II), equation (6) provides a test for the extent of substitution. If there is no substitution then $\beta_{1}^{F}$ in (6) should be the same as that in (4) i.e. the same as the bank-lending channel effect. At the other extreme, if there is full substitution, all firms will have equal access to lenders regardless of whom they borrowed from initially. In such a scenario, a given bank's liquidity crunch will have no impact on its firm's aggregate borrowing and $\beta_{1}^{F}$ will be zero since all firms will only respond to the aggregate liquidity shock (captured by $\beta_{0}^{F}$ ). More generally, the greater the substitution, the closer $\beta_{1}^{F}$ will be to zero.

Column (1) in Table VI shows that on average firms are unable to compensate for the bank-lending channel by increasing borrowing from more liquid banks. Column (2) separates 
this effect for large and smaller borrowers and shows that while large borrowers almost fully offset their bank's liquidity shock, in stark contrast, the significant interaction term shows that smaller borrowers are unable to hedge the initial liquidity shock faced by their banks. For a one percent decline in their initial banks liquidity, total borrowing for these firms drops by $0.8 \%$, essentially the same result as the bank lending channel for smaller firms. Thus smaller borrowers are unable to avoid the adverse liquidity shock by going to other lenders in the market. ${ }^{17}$

Figure VII presents a non-parametric picture of this size heterogeneity. We compute the same effect separately for each firm borrowing size decile - Figure VII plots the coefficient estimate for each of the size deciles. and shows how it declines for each firm decile (except the smallest decile which probably has a lot of noise). In particular, the top three deciles show almost no effect and justify why we include them in our "large" borrower category.

Column (3) shows that this result remains robust to the inclusion of an extensive set of firm and bank level controls. Firm level controls include dummies for each of the 134 cities/towns the firm is located in, 21 industry dummies, whether the firm is politically connected or not, its membership in a business conglomerate and whether it borrows from multiple banks. Bank level controls include lagged change in bank liquidity, pre-shock bank ROA, log bank size, bank capitalization, fraction of the bank's portfolio in default and dummies for foreign and government banks.

Column (4) adds interactions of firm attributes in addition to size, such as whether the firm is a member of a large conglomerate, whether it is politically connected, and had multiple lenders at the time of nuclear tests. The coefficient on ( $\Delta \log$ Bank Liquidity) is now positive and significant. This suggests that the few large firms that are neither part of a conglomerate nor politically connected also cannot completely hedge their lending channel shocks i.e. being large alone is not sufficient. ${ }^{18}$

We should clarify at this point that we do not know the fundamental reason why large firms, or connected firms are able to substitute out of their lending channel shocks. The results of Table VI should be seen as more descriptive, i.e. we identify the set of firms that are able to

\footnotetext{
${ }^{17}$ We still cluster observations at the bank level in Table VI. However since observations across banks are aggregated at the firm level, for multiple-relationship firms we use the largest lender of a firm as the unit of clustering. Similarly, for multiple relationship firms, "bank controls" are constructed by value-weighing bank data for each of the banks a firm borrows from.

${ }^{18}$ Only $11.8 \%$ of lending within large firms goes to firms that are neither politically affiliated nor connected through a business conglomerate.
} 
hedge their lending channel shocks. Our data does not allow us to test whether this ability to hedge is due to some inherent productivity advantage of these firms or whether these firms can exercise some "power" to get favors from banks. Our earlier work on political rent seeking (Khwaja and Mian, 2005) suggests that firm connections might provide leverage in adverse times.

How do large and connected firms substitute away their lending channel shocks? The ability to do so is not driven by ex-ante hedging, i.e. it is not the case that these firms were borrowing from one bank that received a negative shock and another that received a positive shock. This can partially be seen from column (4) as well that shows that borrowing from multiple banks has no independent power in explaining hedging. Another way to analyze this is to compare the standard deviation of bank liquidity shocks with the standard deviation of these shocks within and between firms. Table I shows that the standard deviation of bank liquidity shocks is $30 \%$. The between firm variation in bank liquidity shocks, i.e. standard deviation of the loan-weighted liquidity shock $\left(\Delta \bar{D}_{j}\right)$ at the firm level is $22.9 \%$, and the standard deviation of liquidity shocks within firms is $19.3 \%$. The distribution of liquidity shocks is thus very similar between banks, between firms, and within firms. Hedging is therefore an active ex-post phenomena.

Table VII further explores how large firms hedge their lending channel shocks by separately examining a firm's overall borrowing after the shock from its existing banks and new banks. Column (1) first looks at overall borrowing post-shock from the banks a firm was already borrowing from prior to the shock. For every percent decrease in their banks' liquidity, large borrowers face a $0.15 \%$ drop in their aggregate borrowing.

Column (2) then looks at aggregate borrowing changes from banks a firm was not borrowing from before the shock. These changes are measured relative to the firm's total borrowing before the shock. The result shows that large borrowers also hedge by being able to borrow more from banks they were not borrowing from before i.e. the negative coefficient implies that if a large firm's existing banks suffered an average negative liquidity shock, the firm is able to borrow more from new banks. The coefficient in column (2) is not directly comparable to that in column (1) since it measures the sensitivity of borrowing from new banks to the old banks' average liquidity shock. Results from Table IV (columns (4) and (5)) already show that these new banks are more likely to be ones with a positive liquidity shock. Column (3) repeats the same regression as in Table VI column (3) to provide an idea of how much of the hedging large 
borrowers obtain is from pre-existing banks. ${ }^{19}$

In terms of the relative magnitude of hedging from existing and new banks, the OLS estimate for the bank lending channel for large borrowers is $0.30 \%$ (column (6) of Table III). This suggests that large borrowers compensate half of their loan loss by going to (relatively more) liquid preexisting banks and the remaining half by borrowing from (more liquid) banks with whom they did not have a prior relationship.

\section{B. Firm Financial Outcomes}

If the lending channel shocks effect the aggregate borrowing of small but not large firms, one might expect only the former to experience any real impact of bank liquidity shocks. However, even the average smaller borrowers may not be adversely affected if they can compensate for the lower aggregate external borrowing by tapping into internal cash reserves or other forms of informal financing such as trade credit and family loans. If these internal and informal means of financing are sufficient, then a reduction in external financing might have little or no impact on a firm's real outcomes.

While we do not have firm level output data, we do observe whether a firm goes into financial distress (default). We can thus test whether bank liquidity shocks also translate into a real impact at firm level. We run regression specification (6) with a firm's default rate as the LHS variable. Since cross-default clauses make it unlikely a firm can default on one bank but not the other, and the data shows that this is indeed the case, default rate is aggregated at the firm level.

Column (1) in Table VIII shows that firms that on average experience a reduction in their banks' liquidity experience higher default rates. In particular, a 1\% reduction in liquidity of a bank increases the probability of default of its firm by about 13.7 basis points. Given a mean post nuclear test default rate of 6.9 percentage points, this is a $2 \%$ increase in probability. Recall that our identification strategy suggests that the increase in default rate of firms more exposed to a liquidity crunch cannot be attributed to unobserved negative productivity shocks experienced by such firms and that, if anything, this bias leads to an underestimate. In the

\footnotetext{
${ }^{19}$ Note that that the Column (1) and (2) coefficents can't be simply averaged to obtain the Column (3) coefficient both because the weights are not equal - they depend on the average share of the firm's borrowing from old and new banks (it is smaller for new) - and because the log-log specification used implies the coefficient is only an approximate weighted average (holds for small liquidity shocks).
} 
absence of a liquidity shock to their banks, these firms are unlikely to have had differentially higher default rates.

Thus not only does a liquidity crunch reduce overall lending to firms, but it also makes it more likely for the affected firms to enter financial distress. This is particularly important since it suggests that firms cannot compensate their loss of formal credit through informal channels such as drawing on internal capital or borrowing from sister/family firms.

If higher default rates for firms borrowing from more credit-crunched banks is due to reduced loans to the firms, we should see the same relationship between change in default rates and change in a firm's loans. In general, change in loan supply is endogenous to changes in a firm's demand conditions. A potential instrument for change in a firm's loan supply is the firm's bank's liquidity. ${ }^{20}$ Column (2) instruments the change in a firm's loans by the change in its bank's liquidity and shows an even larger effect on a firm's default rate of a reduction in its loan supply.

Recall that column (2) in Table VI showed that larger borrowers experienced little/no reduction in aggregate borrowing due to their ability to hedge the bank specific shocks while smaller borrowers were unable to do so. If default rates increase due to the credit constraints faced by firms, one would expect the impact on default rates to be higher for smaller borrowers. This is confirmed in column (3). The results show that large borrowers experience no significant increase in their default rates when borrowing from liquidity constrained banks. However, in sharp contrast, smaller borrowers are affected adversely by the shock and are significantly more likely to go into financial distress. A $1 \%$ decrease in their banks' liquidity leads to about 16 basis points increase in their probability of default. Column (4) includes the full set of bank and firm level controls and results remain qualitatively unchanged.

Column (5) shows that this result is not affected if we allow for heterogeneity across other firms attributes. However, having connections to a large conglomerate has independent advantages of its own in terms of not suffering the negative consequences of bank liquidity shocks. Note that we cannot run IV in columns (3) and (4) because as Table VI showed, the first stage does not hold for large borrowers. These results suggest that the liquidity shock has real financial consequences that vary starkly across large and smaller borrowers - the former remain

\footnotetext{
${ }^{20}$ The first stage for this instrument is given in Table IV. To the extent that bank's experiencing greater liquidity shocks only affect their client firm's financial condition through the amount lent, the exclusion restriction for the instrument would be satisfied.
} 
protected from the shock while the latter face its full brunt.

\section{Concluding Remarks}

The aim of this study was to trace how supply side bank liquidity shocks get transmitted to the rest of the economy. Our firm fixed effects approach provides a new way of isolating the credit supply channel by absorbing any credit demand shocks at firm level. Since the data used in this paper is potentially available in many other countries as well, our methodology can be applied more widely to understand the lending channel transmission mechanism.

While the bank lending channel identified in this paper is large regardless of the type of borrowing firm, a particular subset of firms can hedge the adverse effects of lending channel by forming new banking relationships and borrowing more from more liquid banks. Firms that are able to do so successfully are large connected firms.

Since about 90 percent of lending goes to such firms that can hedge completely, one could argue that bank liquidity shocks have no significant aggregate effects. However, given that almost $70 \%$ percent of firms (by number) cannot hedge the negative lending channel shocks and consequently get exposed to increased likelihood of financial distress, bank liquidity shocks have serious long term distributional implications. These distributional changes are likely to last not only due to the persistence of the initial effect, but also as they get reinforced through the series of liquidity shocks that hit economies. Macro shocks may therefore contribute to the "missing middle" in firm size distribution one often documents in emerging markets.

The inability of small unconnected firms to hedge suggests that the fixed costs of forming new banking relationships might be an important constraint in financial markets. Certain firms might be able to use their size or corporate and political affiliations to "buy" their way into preferential banking relationships. While this insurance due to size and linkages may be specific to our environment, it is likely that some form of firm heterogeneity exists in other, particularly emerging economy, environments as well. Therefore, how the corporate sector responds and evolves in response to large financial shocks and how these corporate structures in turn influence financial market reforms both offer fruitful areas of future research. 


\section{Appendix I: Firm Attributes}

Details on the firm attributes used in this paper:

(i) Politically Connected. An indicator variable which is equal to 1 if one of the directors of the firm ran in a national or provincial election during the 1993 or 1997 general elections in Pakistan.

(ii) Size. The total borrowing by a firm from all the banks in the country (including foreign, domestic, and government banks) is used as a proxy for borrower size. Top 30\% of firms by size are classified as "large", and the rest as "small".

(iii) Location. This variable captures which type of city or town the borrower belongs to. Cities are classified by their population size into three categories: big, medium and small. Borrowers located in the three largest cities (city population greater than 2 million) are coded as big, while those in cities with population between 0.5-2 and 0-0.5 million are coded as medium and small respectively. ${ }^{21}$

(iv) Single Relationship. This variable captures whether the firm had single or multiple banking relationships at the time of nuclear tests in May 1998.

(v) Conglomerate. Using information on the names and tax identification numbers of all directors of a firm we can classify firms into business networks based on their ownership information. Firms are assigned to the same network if they have a director in common, i.e. interlocked boards. Forming groups in this way creates two distinct category of firms: (a) Conglomerate Firms - these are firms which belong to the large conglomerates, defined as networks consisting of more than 100 firms each. (b) Non-conglomerate firms - these are remaining firms of whom the vast majority are in networks of 5 or fewer firms.

\footnotetext{
${ }^{21}$ Karachi, Lahore, and Rawalpindi/Islamabad are coded as "big", Faisalabad, Gujranwala, Multan, Sialkot, Sargodha, Peshawar, Quetta, and Hyderabad are coded as "medium", and the remaining cities and towns are coded as "small".
} 


\section{References}

[1] Ashcraft, A. (2006) "New Evidence on the Lending Channel." Journal of Money, Credit, and Banking, Forthcoming

[2] Ashcraft, A. (2005). "Are Banks Really Special? New Evidence from the FDIC-Induced Failure of Healthy Banks." American Economic Review, Volume 95, Number 5.

[3] Ben S. Bernanke (1983), "Non monetary Effects of the Financial Crisis in the Propagation of the Great Depression." The American Economic Review, Vol. 73, No. 3. pp. 257-276.

[4] Bernanke, B. and A. Blinder (1988). "Credit, Money, and Aggregate Demand." American Economic Review 78(2): 435-439.

[5] Bernanke, B. and A. Blinder (1992). "The Federal Funds Rate and the Channels of Monetary Transmission." American Economic Review 82(4): 901-921.

[6] Bernanke, B. and M. Gertler (1989). "Agency Costs, Net Worth, and Business Fluctuations." American Economic Review 79(1): 14-31.

[7] Bernanke, Ben and Harold James, (1991). "The Gold Standard, Deflation and Financial Crises in the Great Depression: An International Comparison,” in R. Glenn Hubbard, ed., Financial Markets and Financial Crises, Chicago: University of Chicago Press, pp. 33-68.

[8] Bertrand, M.; E. Duflo, and S. Mullainathan, (2004). How much should we trust differencesin-differences estimates? Quarterly Journal of Economics, Vol. 119, Issue 1.

[9] Calomiris, C. W andJ. Mason. (2003). "Consequences of Bank Distress During the Great Depression," American Economic Review. (93:3), pp. 937-947.

[10] Fisher, Irving, (1933). "The Debt-Deflation Theory of the Great Depression." Econometrica, $1(4)$, pp. $337-57$.

[11] Gertler, M. and S. Gilchrist, (1994). "Monetary Policy, Business Cycles, and the Behavior of Small Manufacturing Firms", Quarterly journal of Economics, Vol. CIX, May.

[12] Holmstrom, Bengt; and Jean Tirole, (1997). "Financial Intermediation, loanable funds, and the real sector". Quarterly Journal of Economics: 665-691. 
[13] Kashyap, A. and J. Stein, (2000). "What do One Million Observations on Banks Have to Say About the Transmission of Monetary Policy." American Economic Review 90(3): 407-428.

[14] Kashyap, A., O. Lamont and J. Stein, (1994). "Credit Conditions and the Cyclical Behavior of Inventories." The Quarterly Journal of Economics 109(3): 565-592.

[15] Kashyap, A., R. Rajan, and J. Stein, (2002). Banks as Liquidity Providers: An Explanation for the Co-Existence of Lending and Deposit-Taking. Journal of Finance, Vol. LVII, No. 5.

[16] Kashyap, A., J. Stein and D. Wilcox, (1993). "Monetary Policy and Credit Conditions: Evidence from the Composition of External Finance." American Economic Review 83(1): 78-98.

[17] Khwaja, A. and A. Mian, (2005). "Do Lenders Favor Politically Connected Firms? Rent Provision in an Emerging Financial Market", Quarterly Journal of Economics, Vol. 120, Issue 4 .

[18] Paravisini, D (2006). "Local Bank Financial Constraints and Firm Access to External Finance", July 2006 (mimeo, Columbia GSB).

[19] Peek, J. and E. Rosengren, (1997). "The International Transmission of Financial Shock: The Case of Japan" American Economic Review 87(4): 495-505.

[20] Peek, J. and E. Rosengren, (2000). "Collateral Damage: Effects of the Japanese Bank Crisis on Real Activity in the United States." American Economic Review 90(1): 30-45.

[21] Petersen, M. and R. Rajan, (1994). "The Benefits of Lending Relationships: Evidence from Small Business Data." The Journal of Finance 49(1): 3-37.

[22] Stein, J., (1998). "An Adverse Selection Model of Bank Asset and Liability Management with Implications for the Transmission of Monetary Policy." RAND Journal of Economics 29(3): 466-86. 
TABLE I

SUMMARY STATISTICS

\begin{tabular}{|c|c|c|c|c|}
\hline \multicolumn{5}{|c|}{ Panel A : Loan-level Variables (22,176 loans) } \\
\hline Variable & Mean & S.D. & & \\
\hline Pre-nuclear Test Total Lending ('000) & 16,479 & 60,768 & & \\
\hline Change in Log Lending & -0.0028 & 1.23 & & \\
\hline Post-nuclear Test Default Rate & $6.8 \%$ & $26.1 \%$ & & \\
\hline Pre-nuclear Test Interest Rate (\%) & $15.9 \%$ & $2.7 \%$ & & \\
\hline $\begin{array}{l}\text { Loan Type } \\
\text { Percent of total lending }\end{array}$ & $\begin{array}{l}\text { Fixed } \\
32.5 \%\end{array}$ & $\begin{array}{c}\text { Working } \\
\text { Capital } \\
56.1 \%\end{array}$ & $\begin{array}{c}\text { Letter of } \\
\text { Credit } \\
4.2 \%\end{array}$ & $\begin{array}{l}\text { Other } \\
7.2 \%\end{array}$ \\
\hline \multicolumn{5}{|c|}{ Panel B: Borrower/Firm Attributes (18,647 firms) } \\
\hline $\begin{array}{l}\text { Politically Connected } \\
\text { Percent of total lending (of total firms) }\end{array}$ & $\begin{array}{l}\text { No } \\
54 \%(76 \%)\end{array}$ & $\begin{array}{c}\text { Yes } \\
46 \%(24 \%)\end{array}$ & & \\
\hline Size & Small & Large & & \\
\hline Percent of total lending (of total firms) & $6.4 \%(70 \%)$ & $94 \%(30 \%)$ & & \\
\hline $\begin{array}{l}\text { Location (City Size) } \\
\quad \text { Percent of total lending (of total firms) }\end{array}$ & $\begin{array}{c}\text { Small } \\
6 \%(14 \%)\end{array}$ & $\begin{array}{l}\text { Medium } \\
13 \%(18 \%)\end{array}$ & $\begin{array}{l}\text { Large } \\
80 \%(62 \%)\end{array}$ & $\begin{array}{c}\text { Unclassified } \\
6 \%(2 \%)\end{array}$ \\
\hline $\begin{array}{l}\text { Single Relationship } \\
\text { Percent of total lending (of total firms) }\end{array}$ & $\begin{array}{l}\text { Yes } \\
34 \%(90 \%)\end{array}$ & $\begin{array}{l}\text { No } \\
66 \%(10 \%)\end{array}$ & & \\
\hline Business Group Size & $\begin{array}{l}\text { Non- } \\
\text { conglomerate }\end{array}$ & Conglomerate & & \\
\hline Percent of total lending (of total firms) & $36 \%(85 \%)$ & $64 \%(15 \%)$ & & \\
\hline \multicolumn{5}{|c|}{ Panel C : Bank Level Variables (42 banks) } \\
\hline Variable & Mean & S.D. & & \\
\hline Bank Assets Dec '97 & 33886.3 & 63884.7 & & \\
\hline Average ROA ('96 \& '97) & 0.013 & 0.027 & & \\
\hline Capitalization Rate ('96 \& '97) & 0.082 & 0.054 & & \\
\hline Percentage of Dollar Deposits (Dec '97) & 0.60 & 0.27 & & \\
\hline Average Default Rate ('96 \& '97) & 0.086 & 0.13 & & \\
\hline Growth in Deposits (Dec '97 to Dec '99) & 0.046 & 0.30 & & \\
\hline Bank Type & Private & Foreign & Government & \\
\hline Percent of total lending & $33.8 \%$ & $36.8 \%$ & $29.4 \%$ & \\
\hline
\end{tabular}

A "loan" is defined as a Bank-Firm pair, i.e. multiple loans of a firm from the same bank are aggregated up. The loan level data comprises all performing loans given out by the forty two commercial banks at the time of nuclear test that continued to be serviced. The pre and post data is averaged over June 1996 to March 1998, and June 1998 to March 2000 respectively. Note that since we only include performing prenuclear loans, default rate just prior to nuclear tests is zero by construction. Loan Interest Rate in Panel A is available for 39 banks only. Politically Connected $=$ dummy for whether firm has a politician on its board; Size = The total borrowing by a firm from all the banks; Small $=$ bottom 70\%; Location = captures type of city/town borrower belongs to: Big ( $>2$ million), Medium (0.5-2 million) and small (<0.5 million). In regressions however, each city/town is included as a separate dummy variable. Single Relationship = firm only borrows from one bank; Group Size = classify firms into "groups" based on interlocked board membership; see Mian and Khwaja [2005];

Congolomerates fims are those that belong to a large network (more than 100 firms). 
TABLE II

BANK LEVEL CORRELATIONS WITH PRE-TEST DOLLAR DEPOSIT EXPOSURE

\begin{tabular}{|c|c|c|c|c|c|c|}
\hline \multirow[t]{2}{*}{ Dependent Variable } & \multicolumn{2}{|c|}{$\begin{array}{c}\text { Average Annual Growth in } \\
\text { Bank Deposits (Dec '99 - } \\
\text { Dec '97) }\end{array}$} & \multicolumn{2}{|c|}{$\begin{array}{c}\text { Average Pre-Nuclear Test } \\
\text { Default Rate }\end{array}$} & \multicolumn{2}{|c|}{$\begin{array}{c}\text { Average Pre-Nuclear Test } \\
\text { Bank ROA }\end{array}$} \\
\hline & (1) & (2) & (3) & (4) & (5) & (6) \\
\hline $\begin{array}{l}\text { Percentage of Deposits in } \\
\text { Dollars in Dec ' } 97\end{array}$ & $\begin{array}{l}-0.17 \\
(0.08)\end{array}$ & $\begin{array}{l}-0.30 \\
(0.06)\end{array}$ & $\begin{array}{l}-0.27 \\
(0.06)\end{array}$ & $\begin{array}{l}-0.31 \\
(0.06)\end{array}$ & $\begin{array}{c}0.044 \\
(0.014)\end{array}$ & $\begin{array}{l}0.061 \\
(0.016)\end{array}$ \\
\hline Constant & $\begin{array}{c}0.12 \\
(0.05)\end{array}$ & $\begin{array}{c}0.17 \\
(0.03)\end{array}$ & $\begin{array}{c}0.25 \\
(0.04)\end{array}$ & $\begin{array}{c}0.28 \\
(0.04)\end{array}$ & $\begin{array}{l}-0.013 \\
(0.009)\end{array}$ & $\begin{array}{l}-0.022 \\
(0.009)\end{array}$ \\
\hline Bank-Size Weighted & No & Yes & No & Yes & No & Yes \\
\hline Observations & 42 & 42 & 42 & 42 & 42 & 42 \\
\hline R-squared & 0.09 & 0.4 & 0.33 & 0.38 & 0.2 & 0.26 \\
\hline
\end{tabular}

The regressions examine how dollar-deposit reliant banks were affected by the liquidity shock - Columns (1) and (2) - and how they differed before - Columns (3)-(6). The sample is the forty two commercial banks that were allowed to open dollar deposits and hence were directly affected by the "dollar freeze" as a result of the nuclear tests in May 1998. Average Pre-nuclear test default rate is the loan-size weighted default rate of loans from a given bank over July 1996 to March 1998. The bank level default rate is defined here as a fraction between 0 and 1 . Average prenuclear-test ROA is the average ROA of a bank over fiscal years 1996 and 1997 (years end in December). Robust standard errors in parentheses. 
TABLE III

THE BANK LENDING CHANNEL - INTENSIVE MARGIN

\begin{tabular}{|c|c|c|c|c|c|c|c|}
\hline \multirow[t]{2}{*}{ Dependent Variable } & \multicolumn{7}{|c|}{$\Delta$ Log Loan Size } \\
\hline & $\begin{array}{l}\mathrm{FE} \\
(1)\end{array}$ & $\begin{array}{l}\mathrm{FE} \\
(2)\end{array}$ & $\begin{array}{l}\text { FE } \\
(3)\end{array}$ & $\begin{array}{l}\text { OLS } \\
(4)\end{array}$ & $\begin{array}{l}\text { OLS } \\
(5)\end{array}$ & $\begin{array}{l}\text { OLS } \\
(6)\end{array}$ & $\begin{array}{l}\text { OLS } \\
(7)\end{array}$ \\
\hline$\Delta$ Log Bank Liquidity & $\begin{array}{c}0.60 \\
(0.09)\end{array}$ & $\begin{array}{c}0.63 \\
(0.10)\end{array}$ & $\begin{array}{c}0.64 \\
(0.11)\end{array}$ & $\begin{array}{c}0.46 \\
(0.14)\end{array}$ & $\begin{array}{c}0.64 \\
(0.17)\end{array}$ & $\begin{array}{c}0.30 \\
(0.12)\end{array}$ & $\begin{array}{c}0.33 \\
(0.15)\end{array}$ \\
\hline $\begin{array}{l}\Delta \text { Log Bank Liquidity } \\
* \text { Small Firms }\end{array}$ & & & & & & $\begin{array}{c}0.57 \\
(0.26)\end{array}$ & $\begin{array}{c}0.40 \\
(0.21)\end{array}$ \\
\hline Small Firms & & & & & & $\begin{array}{c}0.18 \\
(0.06)\end{array}$ & $\begin{array}{c}0.24 \\
(0.03)\end{array}$ \\
\hline $\begin{array}{l}\text { Lag } \Delta \text { Log Bank } \\
\text { Liquidity }\end{array}$ & & $\begin{array}{c}0.15 \\
(0.10)\end{array}$ & & & & & $\begin{array}{l}-0.13 \\
(0.14)\end{array}$ \\
\hline $\begin{array}{l}\text { Pre-Shock Avg Bank } \\
\text { ROA }\end{array}$ & & $\begin{array}{l}0.99 \\
(1.73)\end{array}$ & & & & & $\begin{array}{l}-0.27 \\
(1.66)\end{array}$ \\
\hline Log Bank Size & & $\begin{array}{c}0.02 \\
(0.03)\end{array}$ & & & & & $\begin{array}{l}-0.02 \\
(0.03)\end{array}$ \\
\hline $\begin{array}{l}\text { Pre-Shock Bank } \\
\text { Capitalization }\end{array}$ & & $\begin{array}{l}-1.16 \\
(0.97)\end{array}$ & & & & & $\begin{array}{c}0.09 \\
(1.13)\end{array}$ \\
\hline $\begin{array}{l}\text { Pre-Shock Bank } \\
\text { Default Rate }\end{array}$ & & $\begin{array}{c}-0.869 \\
(0.36)\end{array}$ & & & & & $\begin{array}{l}-0.518 \\
(0.32)\end{array}$ \\
\hline Gov. Bank Dummy & & $\begin{array}{c}0.13 \\
(0.06)\end{array}$ & & & & & $\begin{array}{l}-0.01 \\
(0.08)\end{array}$ \\
\hline Foreign Bank Dummy & & $\begin{array}{l}0.01 \\
(0.06)\end{array}$ & & & & & $\begin{array}{l}-0.12 \\
(0.08)\end{array}$ \\
\hline Fixed Effects & Firm & Firm & $\begin{array}{c}\text { Firm }{ }^{*} \\
\text { Loan-Type }\end{array}$ & & & & $\begin{array}{c}\text { Firm } \\
\text { Controls }\end{array}$ \\
\hline Constant & -- & -- & -- & $\begin{array}{l}-0.06 \\
(0.04)\end{array}$ & $\begin{array}{l}-0.04 \\
(0.04)\end{array}$ & $\begin{array}{l}-0.14 \\
(0.03)\end{array}$ & -- \\
\hline No of Obs & 5,382 & 5,382 & 5,382 & 5,382 & 22,176 & 22,176 & 22,176 \\
\hline R-sq & 0.44 & 0.44 & 0.6 & 0.01 & 0.02 & 0.03 & 0.05 \\
\hline
\end{tabular}

These regressions examine the bank-lending channel for the set of firms borrowing at the time of the shock (the intensive margin) in more detail. All quarterly data for a given loan is collapsed to a single pre and post nuclear test period. The nuclear test occurred in the 2nd Quarter of 1998, so all observations from Quarter 31996 to Quarter 11998 for a given loan are time-averaged into one. Similarly, all observations from 3rd Quarter 1998 to 1st Quarter 2000 are time-averaged into one. Data is restricted to: (i) banks that take retail (commercial) deposits (78\% of all formal formal financing), and (ii) loans that were not in default in the first quarter of 1998 (i.e. just before the nuclear tests). Columns (1)-(4) are run on the sample of firms that borrow from multiple banks (pre-shock) and include firm fixed effects (firm interacted with loan type for Column 4). Columns (5)-(7) also include firms borrowing from single banks and run an OLS specification. Firm controls in column (7) include include dummies for each of the 134 cities/towns the firm is located in, 21 industry dummies, whether the firm is politically connected or not, its membership in a business conglomerate and whether it borrows from multiple banks. Standard Errors in parentheses are clustered at the bank level (42 banks in total). 
TABLE IV

THE BANK LENDING CHANNEL - EXTENSIVE MARGIN

\begin{tabular}{|c|c|c|c|c|c|c|}
\hline \multirow[t]{2}{*}{ Dependent Variable } & \multicolumn{3}{|c|}{ Exit? } & \multicolumn{3}{|c|}{ Entry? } \\
\hline & $\begin{array}{c}\mathrm{FE} \\
(1)\end{array}$ & $\begin{array}{c}\mathrm{FE} \\
(2)\end{array}$ & $\begin{array}{c}\text { OLS } \\
(3)\end{array}$ & $\begin{array}{l}\mathrm{FE} \\
(4)\end{array}$ & $\begin{array}{l}\mathrm{FE} \\
(5)\end{array}$ & $\begin{array}{c}\text { OLS } \\
(6)\end{array}$ \\
\hline$\Delta$ Log Bank Liquidity & $\begin{array}{l}-0.21 \\
(0.05)\end{array}$ & $\begin{array}{l}-0.19 \\
(0.05)\end{array}$ & $\begin{array}{c}-0.16 \\
(0.059)\end{array}$ & $\begin{array}{c}0.12 \\
(0.05)\end{array}$ & $\begin{array}{c}0.15 \\
(0.04)\end{array}$ & $\begin{array}{c}0.087 \\
(0.049)\end{array}$ \\
\hline Small & & & $\begin{array}{c}0.084 \\
(0.019)\end{array}$ & & & $\begin{array}{c}0.2 \\
(0.015)\end{array}$ \\
\hline Small $* \Delta$ Log Bank Liquidity & & & $\begin{array}{c}0.077 \\
(0.084)\end{array}$ & & & $\begin{array}{c}0.11 \\
(0.067)\end{array}$ \\
\hline Constant & -- & -- & -- & -- & -- & -- \\
\hline Firm Fixed Effects & Yes & Yes & & Yes & Yes & \\
\hline Bank Controls & & Yes & Yes & & Yes & Yes \\
\hline Firm Controls & & & Yes & & & Yes \\
\hline No of Obs & 6,517 & 6,517 & 26,730 & 8,516 & 8,516 & 35,921 \\
\hline R-sq & 0.48 & 0.49 & 0.09 & 0.54 & 0.55 & 0.21 \\
\hline
\end{tabular}

These regressions examine how the bank-lending channel affected exit and entry of firms (from borrowing). Data is restricted to: (i) banks that take retail (commercial) deposits (78\% of all formal formal financing), and (ii) loans that were not in default in the first quarter of 1998 (i.e. just before the nuclear tests). Columns (1)-(3) look at exit by including all loans that were outstanding at the time of the nuclear tests. For a given loan, "exit" is classified as 1 if the loan is not renewed and the firm exits its banking relationship by the first post-shock year. Columns (1)-(2) further limit the sample to only firms that were borrowing from multiple banks before the shock and include firms fixed effects. Columns (4)-(6) look an entry and include all loans given out after the nuclear tests quarter. For a given loan, "entry" is classified as 1 if the loan was made for the first time in the post-shock year. Columns (4)-(5) further limit the sample to only firms that were borrowing from multiple banks after the shock and include firms fixed effects.

All regressions include bank level controls: lagged change in bank liquidity, pre-shock bank ROA, log bank size, bank capitalization, fraction of portfolio in default and dummies for foreign and government banks. The OLS regressions also include an extensive set of firm level controls that include dummies for each of the 134 cities/towns the firm is located in, 21 industry dummies, whether the firm is politically connected or not, its membership in a business conglomerate and whether it borrows from multiple banks. Standard Errors in parentheses are clustered at the bank level (42 banks in total). 
TABLE V

LIQUIDITY IMPACT ON INTEREST RATES

\begin{tabular}{|c|c|c|c|c|}
\hline \multirow[t]{3}{*}{ Dependent Variable } & \multicolumn{4}{|c|}{$\Delta$ Interest Rate } \\
\hline & (1) & (2) & (3) & (4) \\
\hline & $\mathrm{FE}$ & $\mathrm{FE}$ & OLS & OLS \\
\hline \multirow[t]{2}{*}{$\Delta$ Log Bank Liquidity } & 0.28 & 0.33 & 1.53 & -0.43 \\
\hline & $(0.16)$ & $(0.21)$ & $(1.02)$ & $(0.67)$ \\
\hline \multirow[t]{2}{*}{ Small Firms } & & & & 0.20 \\
\hline & & & & $(0.21)$ \\
\hline$\Delta \log$ Bank Liquidity $*$ Small Firms & & & & 0.64 \\
\hline
\end{tabular}

\section{Fixed Effects}

Bank Controls

Firm Controls

Constant

No of Obs

R-sq
Firm

Firm *

Loan-Type

Loan-Type

Yes

$--$

$--$

$-1.59$

(0.34)

$\begin{array}{cccc}5,161 & 5,161 & 21,769 & 21,769 \\ 0.43 & 0.57 & 0.02 & 0.13\end{array}$

These regressions examine the impact of the liquidity shock on interest rates. The interest rate data is not available for each loan but at the bank branch level for different loan size classifications. Using a borrower's bank branch and loan size information we can then create a "proxy" loan-level interest rate. All quarterly data for a given loan is then collapsed to a single pre and post nuclear test period. The nuclear test occurred in the 2nd Quarter of 1998, so all observations from Quarter 31996 to Quarter 11998 for a given loan are time-averaged into one. Similarly, all observations from 3rd Quarter 1998 to 1 st Quarter 2000 are time-averaged into one. Data is restricted to: (i) banks that take retail (commercial) deposits (78\% of all formal financing), and (ii) loans that were not in default in the first quarter of 1998 (i.e. just before the nuclear tests).

Columns(1)-(2) further restrict the data to firms that were borrowing from multiple banks pre-shock (in order to include firms fixed effects). Column (4) includes additional bank and firm level controls. The bank controls are the lagged change in bank liquidity, pre-shock bank ROA, log bank size, bank capitalization, fraction of portfolio in default and dummies for foreign and government banks. Additional firm level controls are dummies for each of the 134 cities/towns the firm is located in, and 21 industry dummies. Standard Errors in parentheses are clustered at the bank level (42 banks in total). 
TABLE VI

THE FIRM BORROWING CHANNEL

\begin{tabular}{|c|c|c|c|c|}
\hline \multirow[t]{2}{*}{ Dependent Variable } & \multicolumn{4}{|c|}{$\Delta$ Log Aggregate Loan Size } \\
\hline & OLS & OLS & OLS & OLS \\
\hline & $(1)$ & $(2)$ & $(3)$ & (4) \\
\hline \multirow[t]{2}{*}{$\Delta$ Log Bank Liquidity } & 0.65 & 0.04 & 0.00 & 0.29 \\
\hline & $(0.04)$ & $(0.09)$ & $(0.09)$ & $(0.11)$ \\
\hline \multirow[t]{2}{*}{ Small Firms } & & 0.18 & 0.19 & 0.28 \\
\hline & & $(0.02)$ & $(0.02)$ & $(0.03)$ \\
\hline \multirow[t]{2}{*}{$\Delta$ Log Bank Liquidity $*$ Small Firms } & & 0.80 & 0.64 & 0.48 \\
\hline & & $(0.10)$ & $(0.10)$ & $(0.12)$ \\
\hline \multirow[t]{2}{*}{ Conglomerate Firm? } & & & & 0.09 \\
\hline & & & & $(0.03)$ \\
\hline$\Delta$ Log Bank Liquidity * Conglomerate & & & & -0.28 \\
\hline Firm & & & & $(0.14)$ \\
\hline \multirow[t]{2}{*}{ Political Firm? } & & & & 0.13 \\
\hline & & & & $(0.02)$ \\
\hline \multirow[t]{2}{*}{$\Delta$ Log Bank Liquidity * Political Firm } & & & & -0.29 \\
\hline & & & & $(0.12)$ \\
\hline \multirow[t]{2}{*}{ Multiple Relationship Firms } & & & & 0.18 \\
\hline & & & & $(0.03)$ \\
\hline$\Delta$ Log Bank Liquidity $*$ Multiple & & & & -0.05 \\
\hline Relationship Firms & & & & $(0.15)$ \\
\hline Bank Controls & & & Yes & Yes \\
\hline Firm Controls & & & Yes & Yes \\
\hline \multirow[t]{2}{*}{ Constant } & 0.04 & -0.08 & -- & \\
\hline & $(0.01)$ & $(0.02)$ & & \\
\hline No of Obs & 18,647 & 18,647 & 18,647 & 18,647 \\
\hline R-sq & 0.02 & 0.03 & 0.05 & 0.06 \\
\hline
\end{tabular}

These regressions examine the impact of the liquidity shock on the total borrowing (across all lending institutions) on firms. All bank loans at a point in time (from any of the 145 lending institutions) for a given firm are summed to compute the aggregate firm level loan size. The liquidity shock experienced by a firm is the (loan-size) weighted liquidity shock experienced by the banks it was borrowing from prior to the shock (lending institutions that do not hold deposits are assigned a liquidity shock of 0 ). All quarterly data for a given firm is then collapsed to a single pre and post nuclear test period. The nuclear test occurred in the 2nd Quarter of 1998, so all observations from Quarter 31996 to Quarter 11998 for a given loan are time-averaged into one. Similarly, all observations from 3rd Quarter 1998 to 1st Quarter 2000 are time-averaged into one. Data is restricted to loans that were not in default in the first quarter of 1998 (i.e. just before the nuclear tests).

Bank level controls include lagged change in bank liquidity, pre-shock bank ROA, log bank size, bank capitalization, fraction of portfolio in default and dummies for foreign and government banks. Firm level controls include dummies for each of the 134 cities/towns the firm is located in, and 21 industry dummies. Standard Errors in parentheses are clustered at the bank level, i.e. the largest lender for a firm. 
TABLE VII

DECOMPOSING THE FIRM BORROWING CHANNEL

Dependent Variable
$\Delta$ Log Aggregate Loan Size

Aggregating Loans Post Test Using Only

$\begin{array}{ccc}\text { Existing Banks } & \text { New Banks } & \text { Existing and New } \\ \text { OLS } & \text { OLS } & \text { OLS }\end{array}$

(1)

(2)

(3)

$\Delta$ Log Bank Liquidity

0.15

$-0.40$

0.04

$(0.09)$

$(0.08)$

(0.09)

Small Firms

0.24

$-0.23$

0.18

(0.02)

(0.02)

(0.02)

$\Delta$ Log Bank Liquidity * Small Firms

0.68

0.53

0.80

(0.08)

Constant

$-0.19$

$-2.55$

$-0.08$

No of Obs

18,647

18,647

18,647

R-sq

0.03

0.03

These regressions explore how firms compensate for their banks liquidity shock. We split a firm's total borrowing post-shock between banks it was borrowing from before the shock (column 1) and banks it started borrowing from after the shock (column 2). The liquidity shock experienced by a firm is the (loan-size) weighted liquidity shock experienced by the banks it was borrowing from prior to the shock (lending institutions that do not hold deposits are assigned a liquidity shock of 0 ). All quarterly data for a given firm is collapsed to a single pre and post nuclear test period. The nuclear test occurred in the 2nd Quarter of 1998, so all observations from Quarter 31996 to Quarter 11998 for a given loan are time-averaged into one. Similarly, all observations from 3rd Quarter 1998 to 1st Quarter 2000 are time-averaged into one. Data is restricted to loans that were not in default in the first quarter of 1998 (i.e. just before the nuclear tests). Standard Errors in parantheses are clustered at the bank level, i.e. the largest lender for a firm.

The bank controls are lagged change in bank liquidity, pre-shock bank ROA, log bank size, bank capitalization, fraction of portfolio in default and dummies for foreign and government banks. Firm level controls include dummies for each of the 134 cities/towns the firm is located in, 21 industry dummies, whether the firm is politically connected or not, its membership in a business conglomerate and whether it borrows from multiple banks. Standard Errors in parentheses are clustered at the bank level, i.e. the largest lender for a firm 


\begin{tabular}{|c|c|c|c|c|c|}
\hline \multirow[t]{2}{*}{ Dependent Variable } & \multicolumn{5}{|c|}{$\Delta$ Firm Default Rate } \\
\hline & $\begin{array}{l}\text { OLS } \\
(1)\end{array}$ & $\begin{array}{l}\text { IV } \\
(2)\end{array}$ & $\begin{array}{l}\text { OLS } \\
(3)\end{array}$ & $\begin{array}{l}\text { OLS } \\
(4)\end{array}$ & $\begin{array}{c}\text { OLS } \\
(5) \\
\end{array}$ \\
\hline$\Delta$ Log Bank Liquidity & $\begin{array}{r}-13.71 \\
(7.44)\end{array}$ & & $\begin{array}{l}2.01 \\
(3.46)\end{array}$ & $\begin{array}{l}-2.36 \\
(3.07)\end{array}$ & $\begin{array}{l}-4.84 \\
(3.80)\end{array}$ \\
\hline$\Delta$ Log Firm Loan & & $\begin{array}{l}-45.46 \\
(12.45)\end{array}$ & & & \\
\hline Small Firms & & & $\begin{array}{l}3.61 \\
(1.18)\end{array}$ & $\begin{array}{c}1.09 \\
(0.90)\end{array}$ & $\begin{array}{c}0.91 \\
(0.91)\end{array}$ \\
\hline $\begin{array}{l}\Delta \text { Log Bank Liquidity } * \\
\text { Small Firms }\end{array}$ & & & $\begin{array}{l}-18.50 \\
(4.57)\end{array}$ & $\begin{array}{l}-13.62 \\
(3.99)\end{array}$ & $\begin{array}{r}-11.50 \\
(3.83)\end{array}$ \\
\hline Conglomerate Firm? & & & & & $\begin{array}{l}-3.41 \\
(0.56)\end{array}$ \\
\hline $\begin{array}{l}\Delta \text { Log Bank Liquidity } * \\
\text { Conglomerate Firm }\end{array}$ & & & & & $\begin{array}{l}10.15 \\
(2.21)\end{array}$ \\
\hline Political Firm? & & & & & $\begin{array}{l}-1.16 \\
(0.58)\end{array}$ \\
\hline $\begin{array}{l}\Delta \text { Log Bank Liquidity } * \\
\text { Political Firm }\end{array}$ & & & & & $\begin{array}{l}-2.27 \\
(1.44)\end{array}$ \\
\hline Multiple Relationship Firms & & & & & $\begin{array}{l}-1.42 \\
(0.85)\end{array}$ \\
\hline $\begin{array}{l}\Delta \text { Log Bank Liquidity } * \\
\text { Multiple Relationship Firms }\end{array}$ & & & & & $\begin{array}{l}-0.11 \\
(2.77)\end{array}$ \\
\hline Bank Controls & & & & Yes & Yes \\
\hline Firm Controls & & & & Yes & Yes \\
\hline Constant & $\begin{array}{l}8.30 \\
(1.35)\end{array}$ & $\begin{array}{c}5.14 \\
(0.75)\end{array}$ & $\begin{array}{c}5.41 \\
(0.77)\end{array}$ & -- & -- \\
\hline No of Obs & 18,647 & 18,647 & 18,647 & 18,647 & 18,647 \\
\hline R-sq & 0.01 & & 0.02 & 0.05 & 0.05 \\
\hline
\end{tabular}

These regressions examine the impact of the liquidity shock on the firm's average default rate. All bank loans at a point in time (from any of the 145 lending institutions) for a given firm are aggregated at the firm level to compute firm default rate, loan size etc. The liquidity shock experienced by a firm is the (loan-size) weighted liquidity shock experienced by the banks it was borrowing from prior to the shock (lending institutions that do not hold deposits are assigned a liquidity shock of 0 ). All quarterly data for a given firm is then collapsed to a single pre and post nuclear test period. The nuclear test occurred in the 2nd Quarter of 1998, so all observations from Quarter 31996 to Quarter 1 1998 for a given loan are time-averaged into one. Similarly, all observations from 3rd Quarter 1998 to 1st Quarter 2000 are time-averaged into one. Data is restricted to loans that were not in default in the first quarter of 1998 (i.e. just before the nuclear tests).

Bank level controls include lagged change in bank liquidity, pre-shock bank ROA, log bank size, bank capitalization, fraction of portfolio in default and dummies for foreign and government banks. Firm level controls include dummies for each of the 134 cities/towns the firm is located in, 21 industry dummies, whether the firm is politically connected or not, its membership in a business conglomerate and whether it borrows from multiple banks. Standard Errors in parentheses are clustered at the bank level, i.e. the largest lender for a firm. 


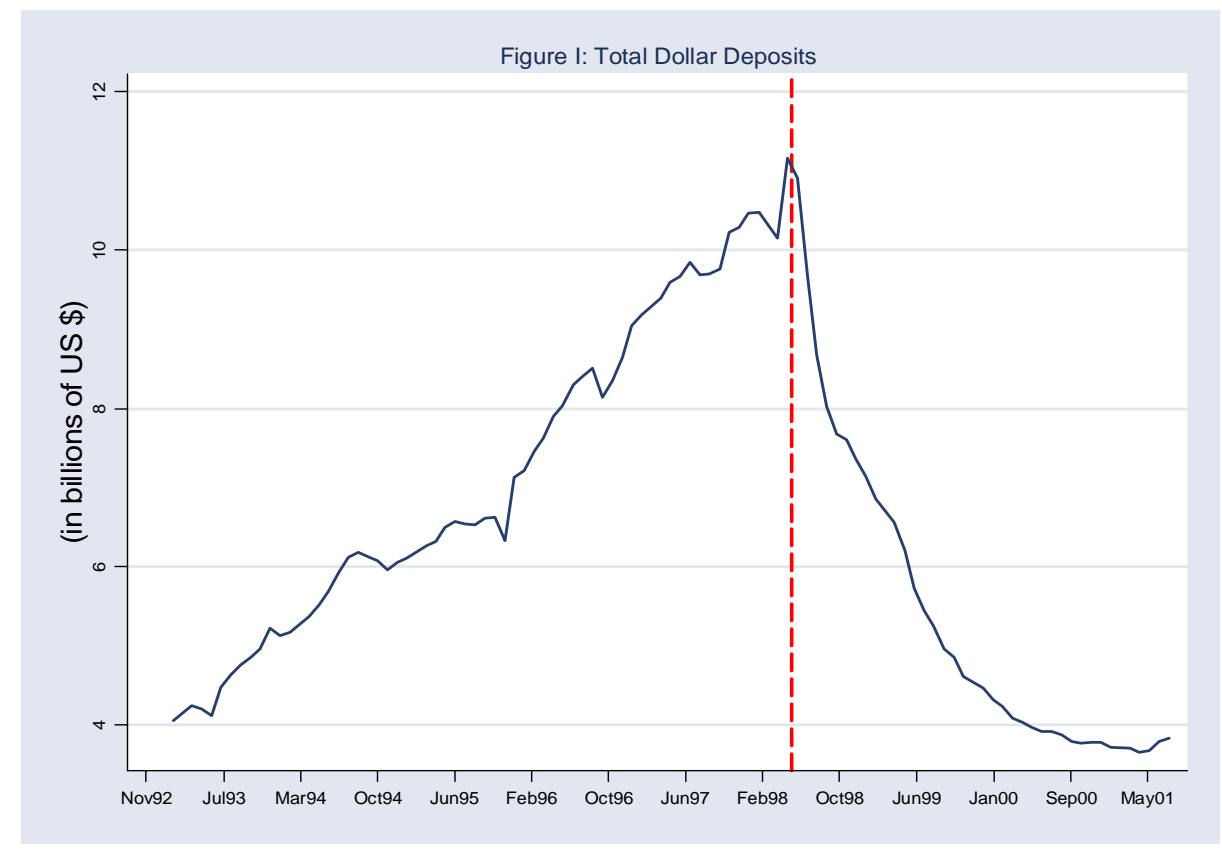

Figure I examines the prevalence of foreign currency deposit accounts in Pakistan. As the Figure shows these accounts, introduced in the early 90s, grew steadily till March 1998, the date of the nuclear shock (indicated by the red line), and then fell rapidly after that.

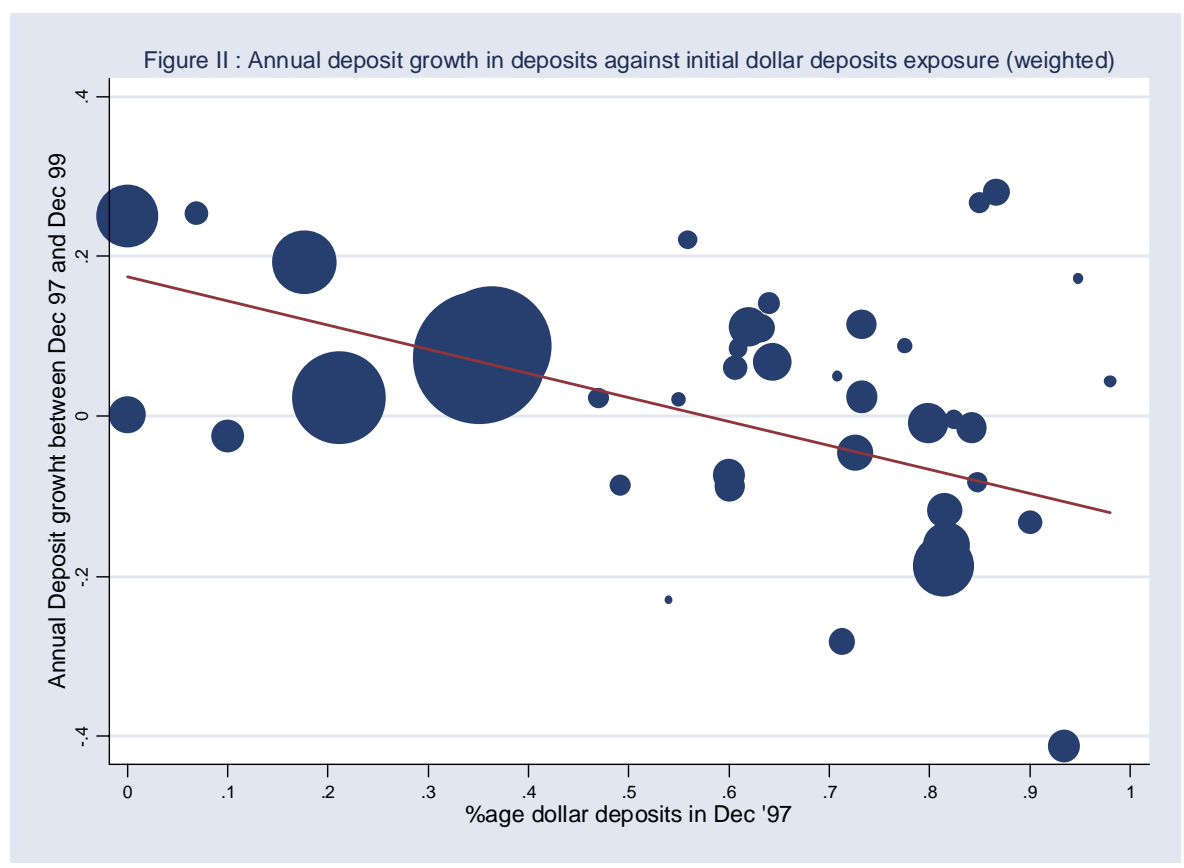

Figure II illustrates the relationship between the change in liquidity/deposit base after the nuclear shock and the percentage of a banks deposits held in foreign currency accounts. Each observation is one of the forty two commercial banks in Pakistan that issued demandable deposits in both local and foreign currency. The y-axis is the annual change in liquidity for these banks from December ' 97 to December '99 and the $\mathrm{x}$-axis is their prenuclear test reliance on dollar deposits. Each observation is plotted proportional to its bank size in December 1997. The graph shows a strong negative relationship between dollar deposit exposure and changes in bank liquidity. 


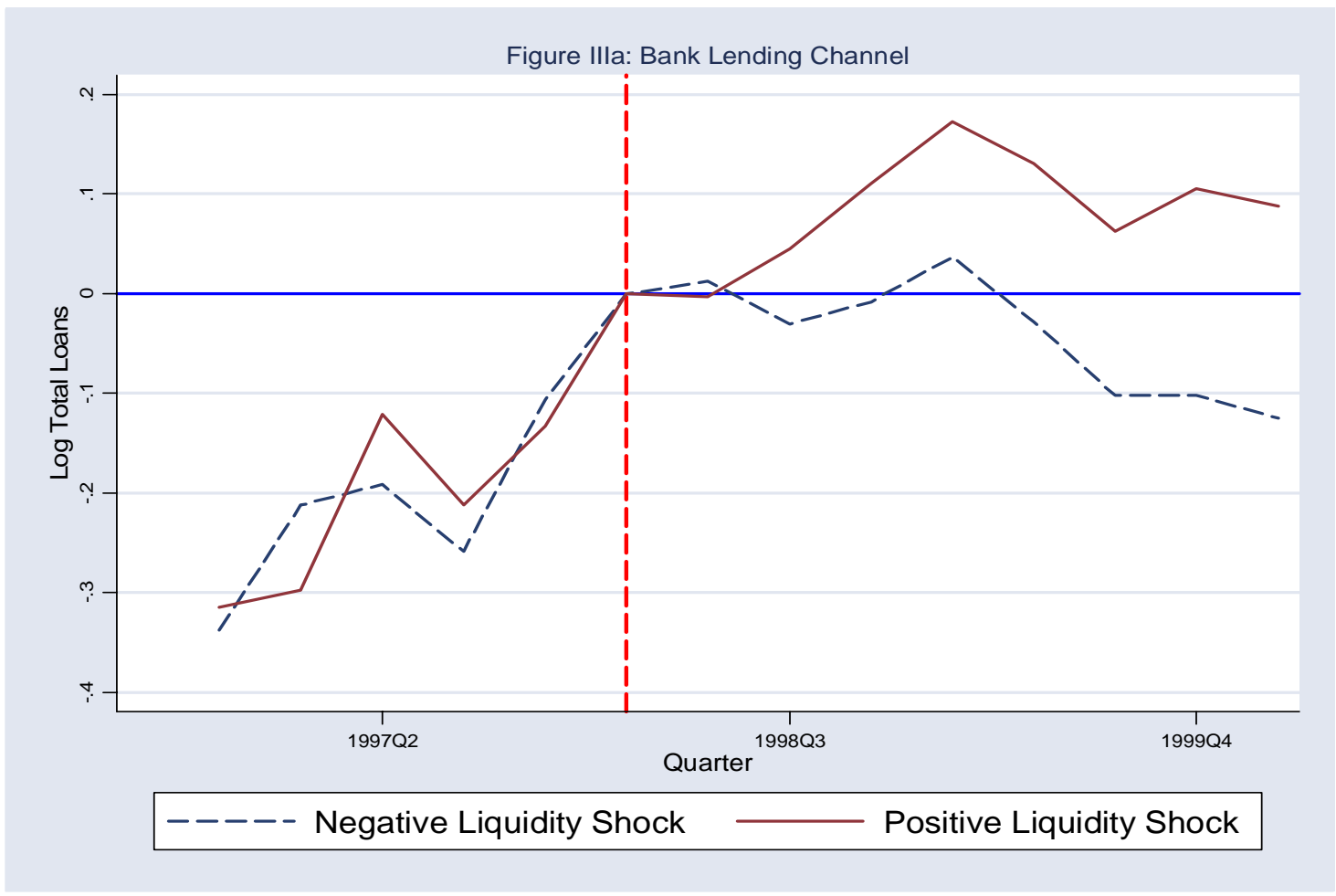

Figure IIIa illustrates the bank-lending channel by comparing lending to firms borrowing from two types of banks: Negative and positive liquidity (shock) banks, with the former defined as banks whose deposit growth was below the median deposit growth in the economy and the latter, banks whose deposit growth was above the median. The figure only includes firms that were borrowing and not in default at the time of the nuclear shock. For each quarter we aggregate all the loans to these firms for the positive and negative liquidity banks and plot the time series for this aggregate lending. To ease comparability we normalize the y-axis so that the logarithm of lending for both positive and negative liquidity banks is forced to be 0 at the time of the shock i.e. the time series illustrates the log-ratio of total loans in a given quarter relative to the quarter of the liquidity shock. The y-axis values can then be readily interpreted as growth rates in lending relative to the nuclear shock quarter. 

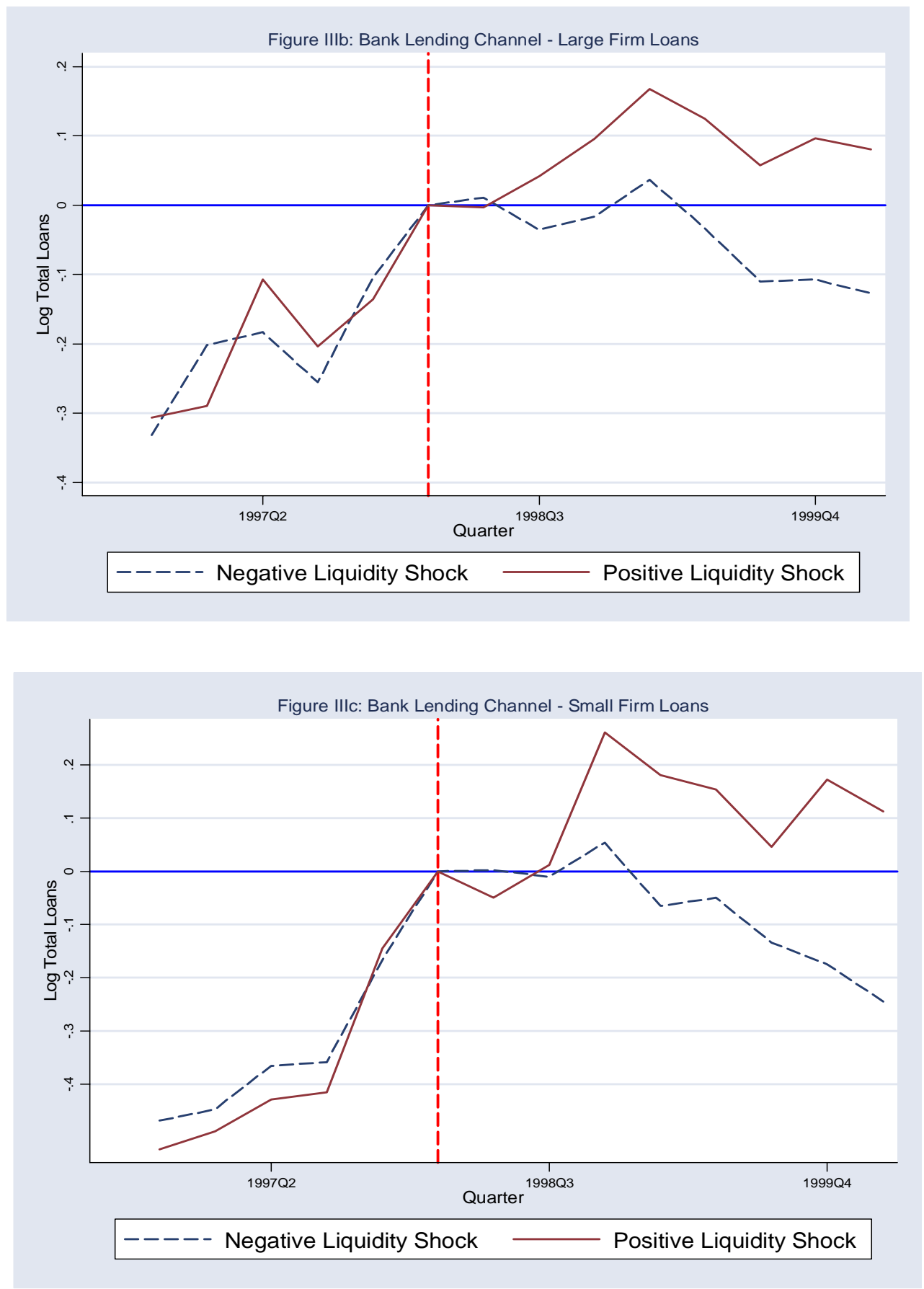

Figures IIIb-c illustrates the bank-lending channel separately for Large (top 30\% by total borrowing) and small (bottom $70 \%$ ) borrowers. We compare lending to large/small firms borrowing from Negative and positive liquidity (shock) banks. The former are defined as banks whose deposit growth was below the median deposit growth in the economy and the latter, banks whose deposit growth was above the median. The figure only includes firms that were borrowing and not in default at the time of the nuclear shock. For each quarter we aggregate all the loans to these firms for the positive and negative liquidity banks and plot the time series for this aggregate lending. To ease comparability we normalize the y-axis so that the logarithm of lending for both positive and negative liquidity banks is forced to be 0 at the time of the shock i.e. the time series illustrates the log-ratio of total loans in a given quarter relative to the quarter of the liquidity shock. The y-axis values can then be readily interpreted as growth rates in lending 

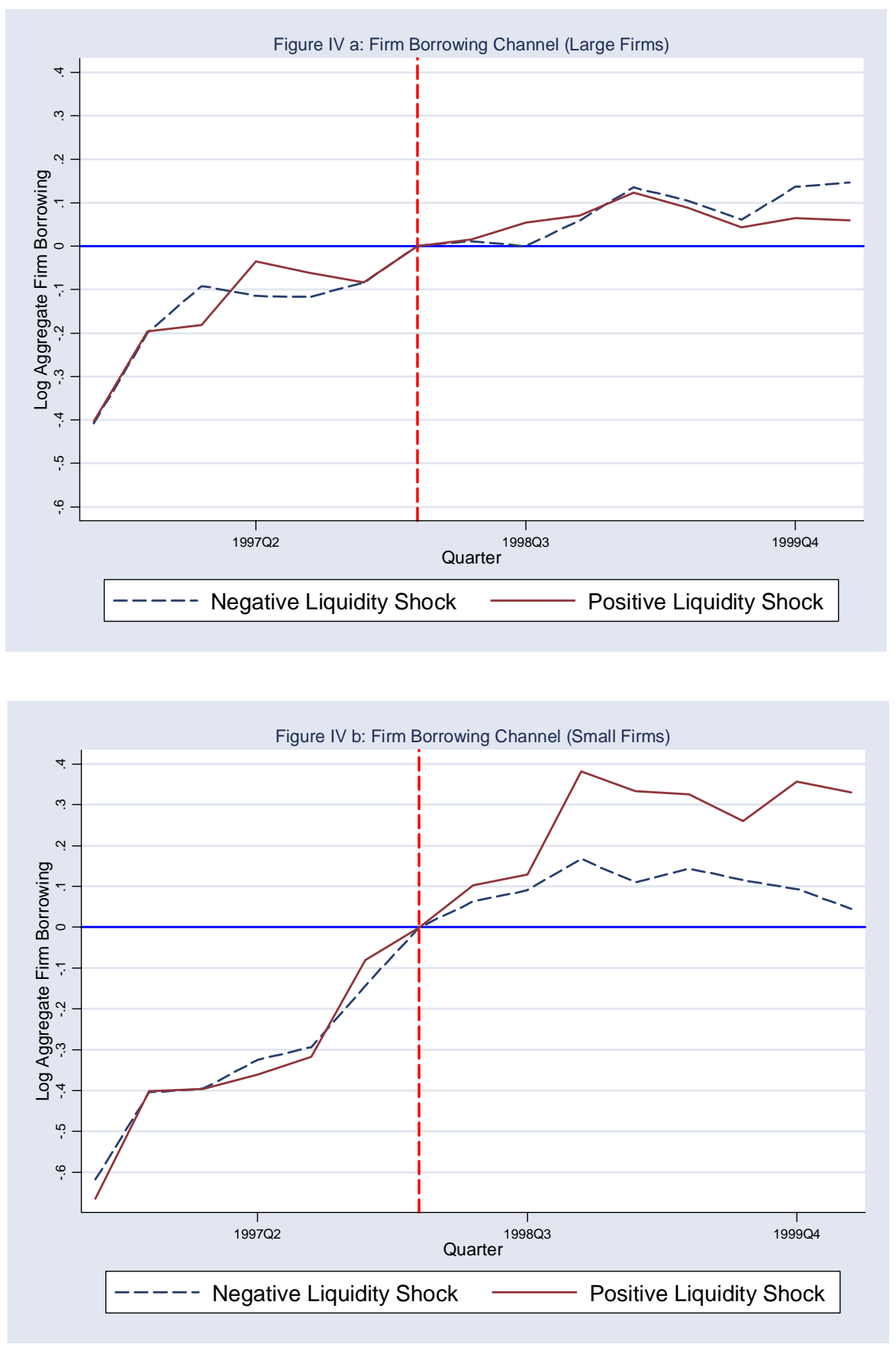

Figures IVa-b illustrate the impact of bank-liquidity shocks on the overall amount a firm is able to borrow. The two figures separately consider large (top 30\% by total borrowing) and small (bottom $70 \%$ ) borrowers. For each quarter, we compare aggregate borrowing of large/small firms by grouping firms into two types: Those that were borrowing from negative or positive liquidity (shock) banks at the time of the nuclear shock. The former are defined as banks whose deposit growth was below the median deposit growth in the economy and the latter, banks whose deposit growth was above the median. The figure only includes firms that were borrowing and not in default at the time of the nuclear shock. For each quarter we aggregate the total amount borrowed by these firms (from all 145 lending institutions). To ease comparability we normalize the $y$-axis so that the logarithm of total borrowing for both firms initially borrowing from positive and negative liquidity banks is forced to be 0 at the time of the shock i.e. the time series illustrates the log-ratio of total borrowing of a firm in a given quarter relative to the quarter of the liquidity shocl 

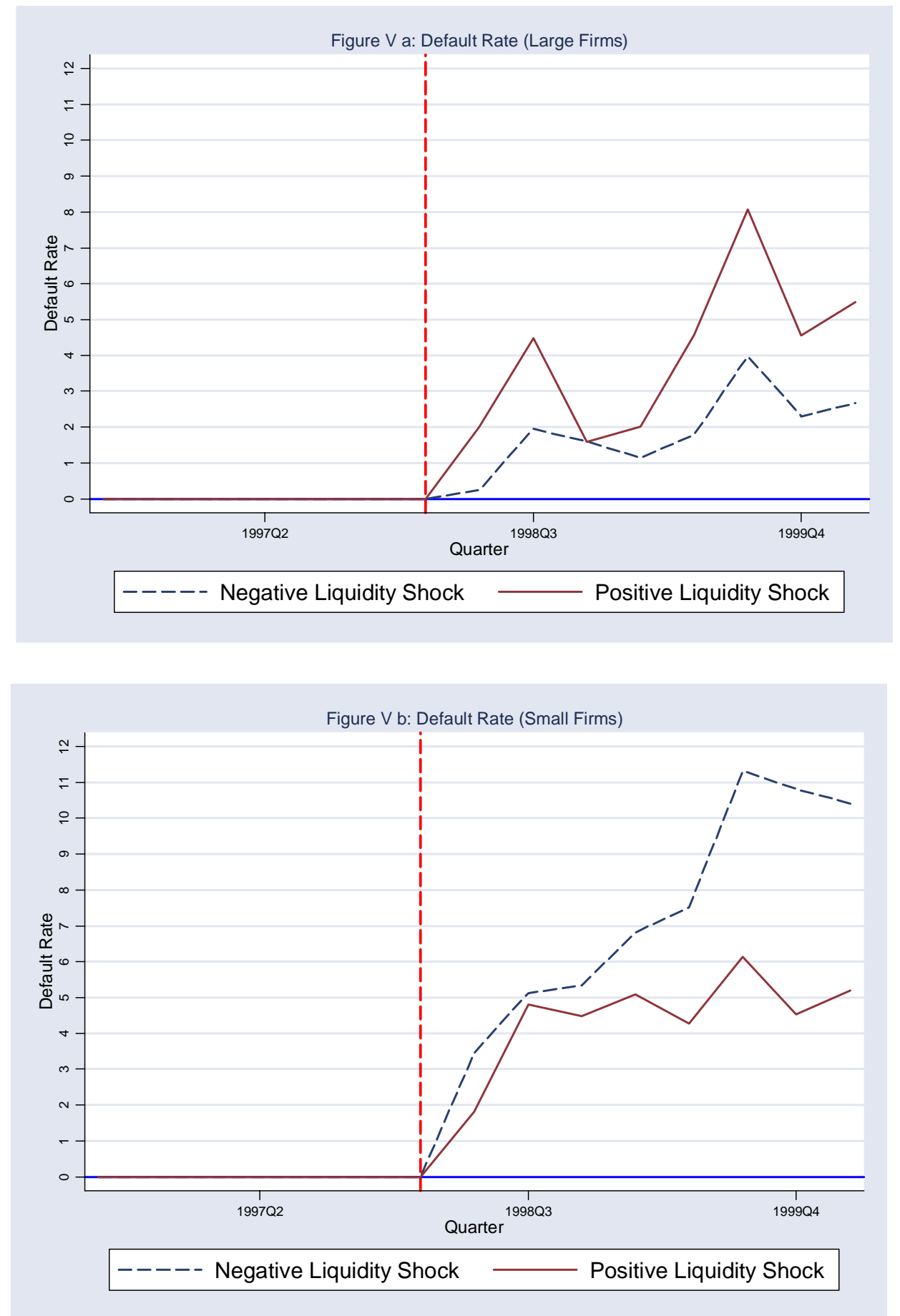

Figures Va-b illustrate the impact of bank-liquidity shocks on firm default rates. The two figures separately consider large (top $30 \%$ by total borrowing) and small (bottom $70 \%$ ) borrowers. For each quarter, we compare average default rates of large/small firms across all their loans (weighted by its loan size) by grouping firms into two types: Those that were borrowing from negative or positive liquidity (shock) banks at the time of the nuclear shock. The former are defined as banks whose deposit growth was below the median deposit growth in the economy and the latter, banks whose deposit growth was above the median. The figure only includes firms that were borrowing and not in default at the time of the nuclear shock. Hence pre-default the default rate time-series is 0 by construction. 


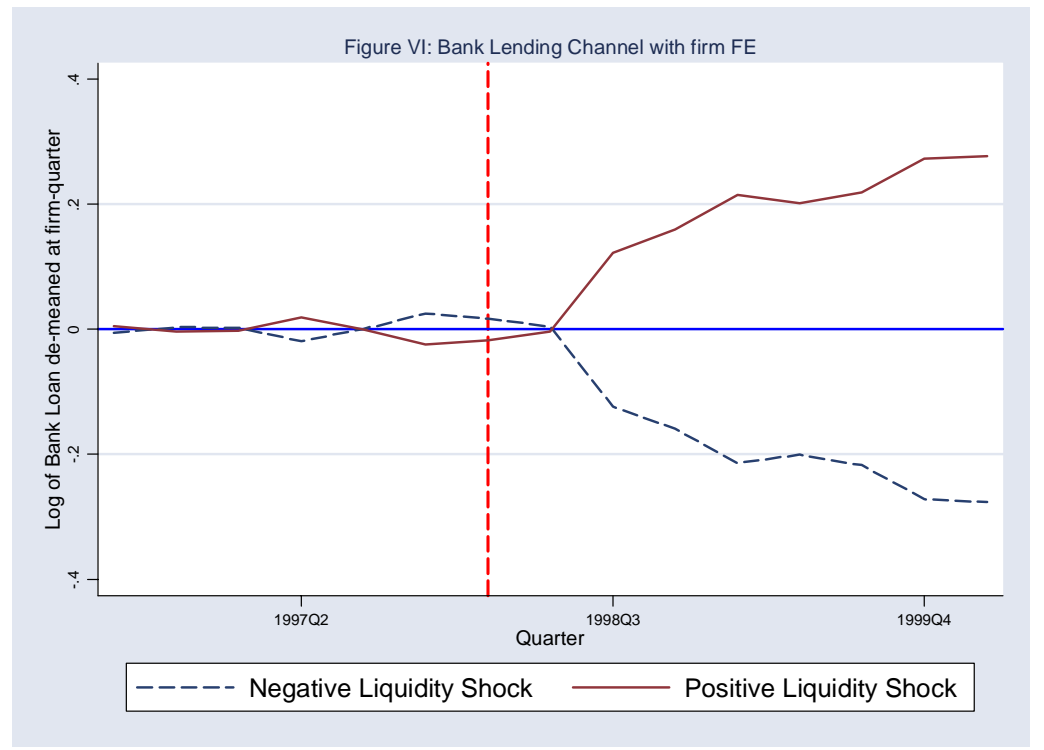

Figure VI illustrates the bank-lending channel by comparing lending WITHIN the same firms that borrow from two types of banks: (relative to the firm's mean bank) Negative and positive liquidity (shock) banks. This figure is the counter-part of the fixed effects regression in Column (1) of Table III. Specifically, we restrict to firms that were borrowing (and not in default) from at least two banks before the shock. For each firm we classify its loans into those from banks that had a change in liquidity greater (positive) or less (negative) than this firm's average bank. We then demean each of the firm's loans (by subtracting the firm's average loan in each quarter). The figure then aggregates all the demeaned negative bank and positive bank loans and plots is logartithm on the y-axis. Given our classification process we are gauranteed that the same firm shows up in both the plotted lines and that one line is the negative mirror image of the other. Given this demeaning, if the bank-lending channel were correctly identified, we would expect to find little/no lending difference between the two series before the shock, but a divergence afterwards. The fig

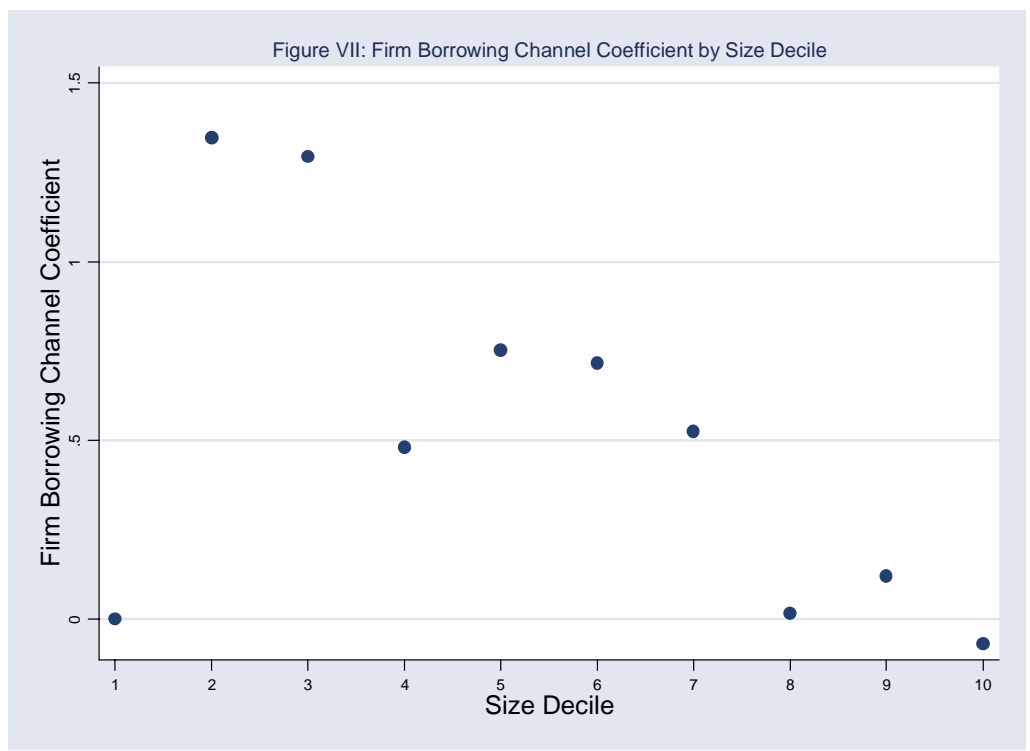

Figure VII illustrates heterogeneity in the impact of bank liquidity shocks on overall firm borrowing for each borrower size decile. It does so by estimating the coefficient from an OLS specification similar to Column (3) of Table VI but where we separately estimate the impact of the liquidity shock on all ten borrower deciles (by pre-shock borrowing size). Apart from the lowest borrower decile (where we have little precision), we see that the impact on overall borrowing for the firm falls for larger borrowers. In fact it is almost non-existent for the largest three borrower deciles (our "large" borrower classification). 